CRYSTALLOGRAPHIC COMMUNICATIONS

ISSN 2056-9890

Received 9 November 2017

Accepted 12 November 2017

Edited by W. T. A. Harrison, University of Aberdeen, Scotland

‡ Additional correspondence author, e-mail: mmjotani@rediffmail.com.

Keywords: crystal structure; carbothioamide; hydrogen bonding; Hirshfeld surface analysis.

CCDC reference: 1585129

Supporting information: this article has supporting information at journals.iucr.org/e

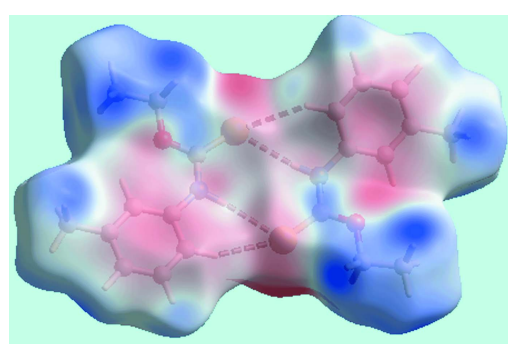

OPEN $\odot$ ACCESS

\section{A new monoclinic polymorph of $\mathrm{N}$-(3-methylphen- yl)ethoxycarbothioamide: crystal structure and Hirshfeld surface analysis}

\author{
Mukesh M. Jotani, ${ }^{a} \neq$ Chien Ing Yeo $^{\mathrm{b}}$ and Edward R. T. Tiekink ${ }^{\mathrm{b} *}$
}

\begin{abstract}
${ }^{a}$ Department of Physics, Bhavan's Sheth R. A. College of Science, Ahmedabad, Gujarat 380001 , India, and ${ }^{\mathbf{b}}$ Research Centre for Crystalline Materials, School of Science and Technology, Sunway University, 47500 Bandar Sunway, Selangor Darul Ehsan, Malaysia. *Correspondence e-mail: edwardt@sunway.edu.my
\end{abstract}

The title compound, $\mathrm{C}_{10} \mathrm{H}_{13} \mathrm{NOS}$, is a second monoclinic polymorph (space group $\left.P 22_{1} / c, Z^{\prime}=2\right)$ of the previously reported $C 2 / c(Z=1)$ polymorph [Tadbuppa \& Tiekink (2005). Z. Kristallogr. New Cryst. Struct. 220, 395-396]. Two independent molecules comprise the asymmetric unit of the new polymorph and each of these exists as a thioamide-thione tautomer. In each molecule, the central CNOS chromophore is strictly planar [r.m.s. deviations = 0.0003 and $0.0015 \AA$ ] and forms dihedral angles of $6.17(5)$ and $20.78(5)^{\circ}$ with the N-bound 3-tolyl rings, thereby representing the major difference between the molecules. The thione-S and thioamide- $\mathrm{N}-\mathrm{H}$ atoms are syn in each molecule and this facilitates the formation of an eight-membered thioamide $\{\cdots \mathrm{SCNH}\}_{2}$ synthon between them; the dimeric aggregates are consolidated by pairwise 3-tolyl-C-H..S interactions. In the extended structure, supramolecular layers parallel to (102) are formed via a combination of 3-tolyl-C$\mathrm{H} \cdot \cdots \pi$ (3-tolyl) and weak $\pi-\pi$ interactions [inter-centroid distance between 3tolyl rings = 3.8535 (12) $\AA$ ]. An analysis of the Hirshfeld surfaces calculated for both polymorphs reveals the near equivalence of one of the independent molecules of the $P 2_{1} / c$ form to that in the $C 2 / c$ form.

\section{Chemical context}

Molecules of the general formula $R \mathrm{OC}(=\mathrm{S}) \mathrm{N}(\mathrm{H}) R^{\prime}[R=$ alkyl, aryl], $O$-thiocarbamates, are readily prepared from the reaction of an alcohol, $R \mathrm{OH}$, with an isothiocyanide derivative, $R^{\prime} \mathrm{N}=\mathrm{C}=\mathrm{S}$. Since the first report of the structure of EtOC $(=\mathrm{S}) \mathrm{N}(\mathrm{H}) \mathrm{Ph}$ (Taylor \& Tiekink, 1994), these molecules have attracted the interest of the crystal engineering community. This interest arises primarily because of the propensity of these molecules to form thioamide-NH...S(thione) hydrogen bonds (Ho et al., 2005; Kuan et al., 2007; Slater et al., 2016) and the ability of these molecules to form co-crystals with pyridyl-like molecules (Ellis et al., 2009). The neutral molecules can complex bis(phosphane)copper(I) chloride to reveal fascinating intramolecular phenyl-C$\mathrm{H} \cdots \pi$ (quasi-chelate ring) interactions where the $\pi$-system is the hydrogen-bond mediated $(\mathrm{CuCl} \cdots \mathrm{HNCS})$ ring (Yeo et al., 2014); intermolecular versions of $\mathrm{C}-\mathrm{H} \cdots \pi$ (quasi-chelate ring) interactions are also known (Zukerman-Schpector et al., 2016). The anions form very stable compounds with phosphanegold(I) moieties to yield luminescent materials in the solid state (Ho et al., 2006) as well as potential anti-bacterial (Yeo et al., 2013) and anti-cancer (Ooi et al., 2017) agents. It was in the latter context that the title polymorph (I) was 
discovered. Thus, (I) was synthesized afresh for complexation to phosphanegold(I) and during characterization exhibited distinctive crystallographic properties from a previously described material, i.e. a C2/c form (Tadbuppa \& Tiekink, 2005), hereafter (Ic). In the present report, the crystal and molecule structures of a new monoclinic polymorph of (I), i.e. (Ip), are described along with a Hirshfeld surface analysis of both polymorphs, conducted in order to discover distinctive packing patterns.

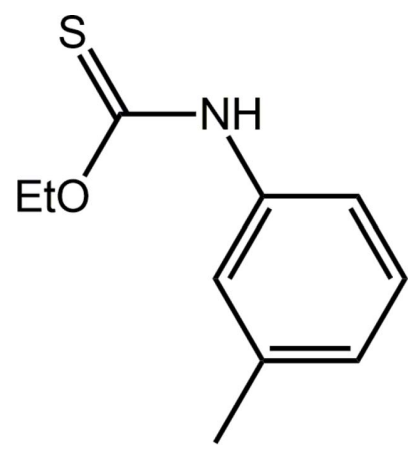

\section{Structural commentary}

The crystallographic asymmetric unit of (Ip), Fig. 1, comprises two independent molecules which are chemically indistinguishable, Table 1 . The thione-S and thioamide- $\mathrm{N}-\mathrm{H}$ atoms are syn in each molecule and each exists as a thioamidethione tautomer. The central $\mathrm{OC}(=\mathrm{S}) \mathrm{N}$ chromophores are strictly planar with the r.m.s. deviation of the four fitted atoms being $0.0003 \AA[0.0015 \AA$ for the S11-molecule]. The bond lengths follow the expected trends with the $\mathrm{C} 1-\mathrm{O} 1, \mathrm{~N} 1$ bonds being significantly shorter than the $\mathrm{C} 9-\mathrm{O} 1$ and $\mathrm{C} 2-\mathrm{N} 1$ bonds, respectively. The angles about the quaternary atom vary systematically, with those involving the thione-S1 atom being greater than the $\mathrm{O} 1-\mathrm{C} 1-\mathrm{N} 1$ bond angle. Of the bond angles involving the thione-S1 atom, the angle involving the $\mathrm{O} 1$ atom is greater by $2-3^{\circ}$ than that formed by the sterically less encumbered $\mathrm{N} 1$ atom. The major difference between the key geometric parameters listed in Table 1 is found in the angles subtended at the $\mathrm{N} 1$ atom with the angle for the S1molecule being nearly $3^{\circ}$ wider than that for the S1-molecule. There is also a conformational difference between the two

Table 1

Selected geometric parameters $\left(\AA,^{\circ}\right)$ in (Ip) and (Ic).

\begin{tabular}{llll}
\hline Parameter & (Ip), S1-molecule & $(\mathrm{Ip})$, S11-molecule & \\
\hline $\mathrm{C} 1-\mathrm{S} 1$ & $1.6768(19)$ & $1.6752(19)$ & $1.6720(18)$ \\
$\mathrm{C} 1-\mathrm{O} 1$ & $1.321(2)$ & $1.319(2)$ & $1.325(2)$ \\
$\mathrm{C} 1-\mathrm{N} 1$ & $1.338(2)$ & $1.339(2)$ & $1.337(2)$ \\
C9-O1 & $1.457(2)$ & $1.454(2)$ & $1.451(2)$ \\
C2-N1 & $1.421(2)$ & $1.423(2)$ & $1.426(2)$ \\
S1-C1-O1 & $124.23(14)$ & $125.00(15)$ & $124.53(12)$ \\
S1-C1-N1 & $122.06(14)$ & $121.61(15)$ & $122.11(13)$ \\
O1-C1-N1 & $113.71(16)$ & $113.39(16)$ & $113.37(15)$ \\
C1-O1-C9 & $118.72(15)$ & $119.01(15)$ & $119.29(15)$ \\
C1-N1-C2 & $132.48(16)$ & $129.60(16)$ & $130.17(15)$ \\
\hline
\end{tabular}

Note: $(a)$ add 10 to atom labels to tally with the numbering in Fig. $1 b$.
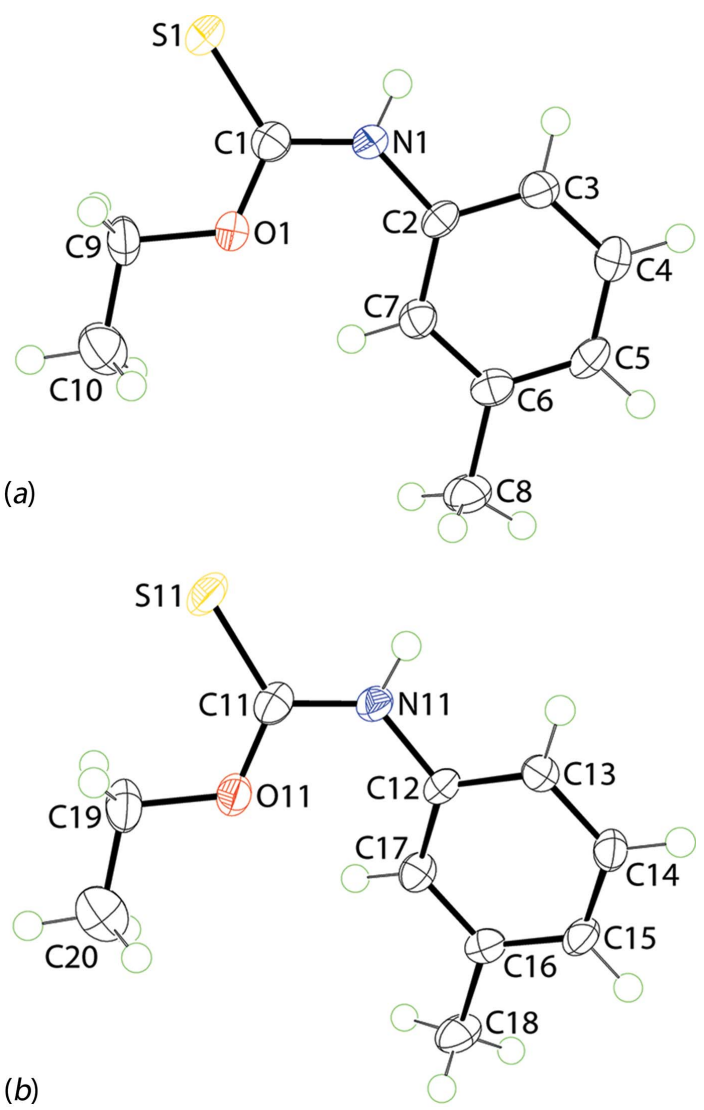

Figure 1

The molecular structures of the two independent molecules comprising the asymmetric unit of (Ip) showing the atom-labelling scheme and displacement ellipsoids at the $70 \%$ probability level.

molecules, readily quantified in terms of the dihedral angles formed between the central chromophore and 3-tolyl rings of 6.17 (5) and $20.78(5)^{\circ}$ for the S1- and S11-molecules, respec-

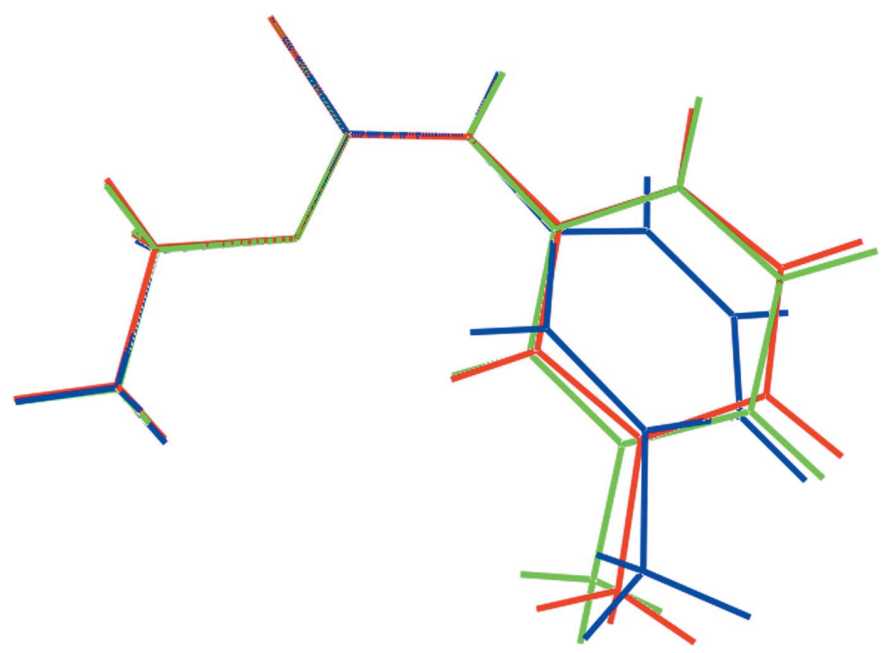

Figure 2

Overlay diagram of the two independent molecules of (Ip) (S1-molecule, red image; S11-molecule, green) and that of the original $C 2 / c$ polymorph (blue image), (Ic). The molecules have been superimposed so that the central $\mathrm{S}, \mathrm{O}$ and $\mathrm{N}$ atoms are coincident. 
Table 2

Hydrogen-bond geometry $\left(\AA{ }^{\circ}\right)$.

$C g 1$ is the centroid of the $(\mathrm{C} 12-\mathrm{C} 17)$ ring.

\begin{tabular}{lllll}
\hline$D-\mathrm{H} \cdots A$ & $D-\mathrm{H}$ & $\mathrm{H} \cdots A$ & $D \cdots A$ & $D-\mathrm{H} \cdots A$ \\
\hline $\mathrm{N} 1-\mathrm{H} 1 N \cdots \mathrm{S} 11$ & $0.87(1)$ & $2.62(1)$ & $3.4859(16)$ & $174(2)$ \\
$\mathrm{N} 11-\mathrm{H} 11 N \cdots \mathrm{S} 1$ & $0.87(1)$ & $2.54(1)$ & $3.3985(15)$ & $171(2)$ \\
$\mathrm{C} 3-\mathrm{H} 3 \cdots \mathrm{S} 11$ & 0.95 & 2.86 & $3.708(2)$ & 150 \\
$\mathrm{C} 13-\mathrm{H} 13 \cdots \mathrm{S} 1$ & 0.95 & 2.94 & $3.7090(19)$ & 139 \\
$\mathrm{C} 17-\mathrm{H} 17 \cdots C g 1^{\mathrm{i}}$ & 0.95 & 2.82 & $3.471(2)$ & 127 \\
\hline
\end{tabular}

Symmetry code: (i) $-x+2, y-\frac{1}{2},-z+\frac{1}{2}$.

tively. As seen from the overlay diagram, Fig. 2, the ethyl groups have an open conformation and overlap closely with the $\mathrm{C} 1-\mathrm{O} 1-\mathrm{C} 9-\mathrm{C} 10$ and $\mathrm{C} 11-\mathrm{O} 11-\mathrm{C} 19-\mathrm{C} 20$ torsion angles being $-178.76(17)$ and $177.42(18)^{\circ}$, respectively.

Geometric parameters for the original polymorph of (I), i.e. (Ic), are also included in Table 1. A comparison of these show the values in (Ip) and (Ic) to be equal within experimental error and those of (Ic) often lying between the two independent values found for (Ip). As evidenced from Fig. 2, there is a greater twist in the molecule as indicated by the dihedral angle of $30.44(6)^{\circ}$ formed between the central chromophore and the 3-tolyl ring. The orientation of the $\mathrm{O}$-bound ethyl group is as for both molecules of (Ip) with the $\mathrm{C} 1-\mathrm{O} 1-\mathrm{C} 9-\mathrm{C} 10$ torsion angle being $-176.96(17)^{\circ}$.

\section{Supramolecular features}

The most notable feature of the molecular packing of (I) is the presence of an eight-membered thioamide synthon, $\{\cdots \mathrm{SCNH}\}_{2}$, formed via thioamide-N-H.SS(thione) hydrogen bonds, between the two independent molecules comprising the asymmetric unit, Fig. 3 and Table 2. As shown in Fig. 3, the $\mathrm{N}-\mathrm{H} \cdots \mathrm{S}$ hydrogen bonds are supported by 3tolyl-C-H. S interactions, Table 2, with that involving the S1 atom being slightly beyond the standard distance criteria in PLATON (Spek, 2009). Globally, like molecules stack along the $b$-axis direction. The S1-molecules are connected via weak $\pi-\pi$ interactions between the 3-tolyl rings with the intercentroid distance being 3.8535 (12) $\AA$ for the symmetry operation $1-x, 2-y, 1-z$. The connections between the S11-molecules are of the type 3-tolyl-C-H $\cdots \pi$ (3-tolyl), Table 2. The columns pack into alternating layers of S1- and S11-molecules parallel to [001], Fig. $4 a$, and connections between them are made through the thioamide- $\mathrm{N}-$ $\mathrm{H}$...S(thione) hydrogen bonds mentioned above, resulting in supramolecular layers parallel to (102), Fig. $4 b$. The layers, Fig. $4 c$, stack with no directional interactions between them.

The molecular packing in (Ic) has not been discussed in any detail (Tadbuppa \& Tiekink, 2005) and hence, is now described. The eight-membered thioamide synthon, $\{\cdots \mathrm{SCNH}\}_{2}$, seen in the packing of (Ip) is also found in the packing of (Ic), Table 3, with an important difference, that being the synthon has crystallographic twofold symmetry; the putative 3 -tolyl-C-H.S interaction is long at $2.92 \AA$.
Table 3

Hydrogen-bond geometry $\left(\AA,^{\circ}\right)$ for (Ic).

$\mathrm{Cg} 1$ is the centroid of the $(\mathrm{C} 2-\mathrm{C} 7)$ ring.

\begin{tabular}{lllll}
\hline $\mathrm{D}-\mathrm{H} \cdots \mathrm{A}$ & $\mathrm{D}-\mathrm{H}$ & $\mathrm{H} \cdots \mathrm{A}$ & $\mathrm{D} \cdots \mathrm{A}$ & $\mathrm{D}-\mathrm{H} \cdots \mathrm{A}$ \\
\hline $\mathrm{N} 1-\mathrm{H} 1 \mathrm{n} \cdots \mathrm{S} 1^{\mathrm{i}}$ & 0.87 & 2.58 & $3.4142(16)$ & 160 \\
$\mathrm{C} 7-\mathrm{H} 7 \cdots C g 1^{\mathrm{ii}}$ & 0.94 & 2.91 & $3.4973(17)$ & 122 \\
\hline
\end{tabular}

Symmetry code: (i) $-x, y, \frac{1}{2}-z$; (ii) $\frac{1}{2}-x,-\frac{1}{2}+y, \frac{1}{2}-z$.

Globally, molecules pack into columns parallel to the $b$ axis and are sustained by 3-tolyl-C-H. $-\pi$ (3-tolyl) interactions, Fig. $4 d$ and Table 3. Connections between columns are made by the aforementioned thioamide- $\mathrm{N}-\mathrm{H} \cdots \mathrm{S}$ (thione) hydrogen bonds. The result is supramolecular layers that stack along the $c$ axis, Fig. $4 e$. A view of the layer is shown in Fig. $4 f$.

From the images of Fig. 4, it is obvious that despite some similarities, the molecular packing in polymorphs (Ip) and (Ic) are distinct. This point is highlighted in the analysis of the Hirshfeld surfaces of (Ip) and (Ic) discussed in the next section.

\section{Analysis of the Hirshfeld surfaces of (Ip) and (Ic)}

The Hirshfeld surfaces for the individual molecules in (Ip), overall (Ip) and for (Ic) were calculated in accord with a recent report on a pair of polymorphs (Kuan et al., 2017). The calculations clearly reveal the similarities and differences in

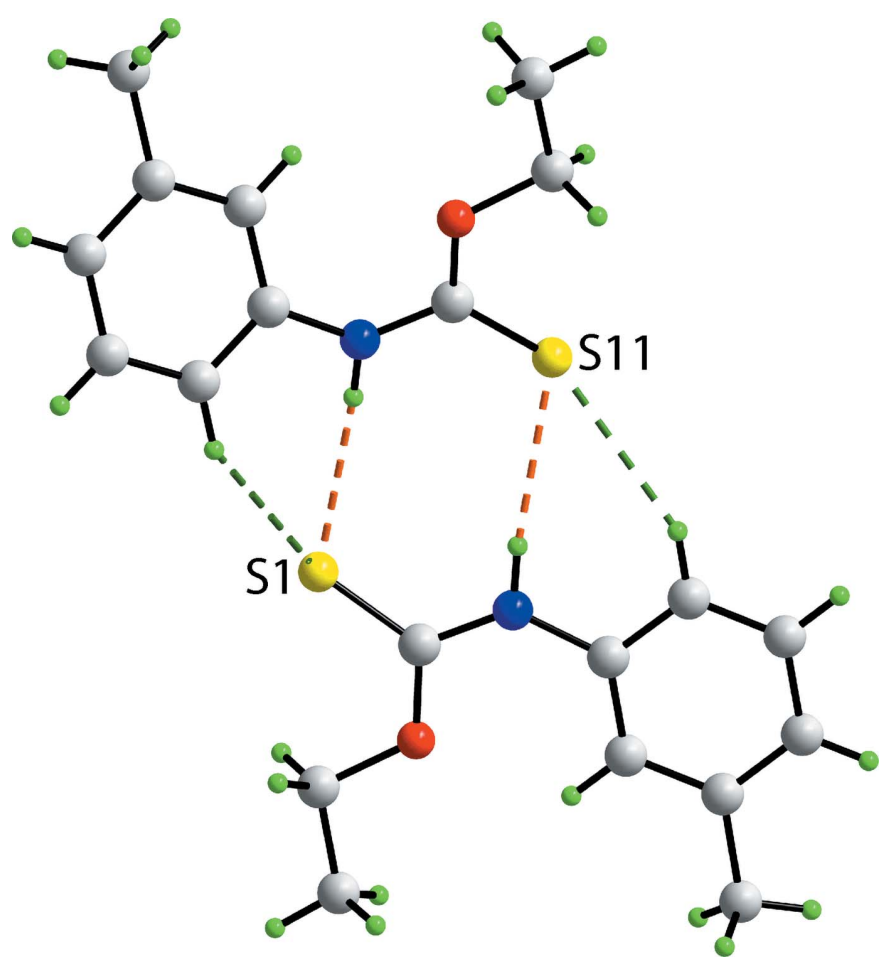

Figure 3

A view of the supramolecular dimer in (Ip) sustained by thioamide-N$\mathrm{H}$...S(thione) hydrogen bonds and supported by 3-tolyl-C$\mathrm{H} \cdots \mathrm{S}$ (thione) interactions, shown as orange and green dashed lines, respectively. 
(a)
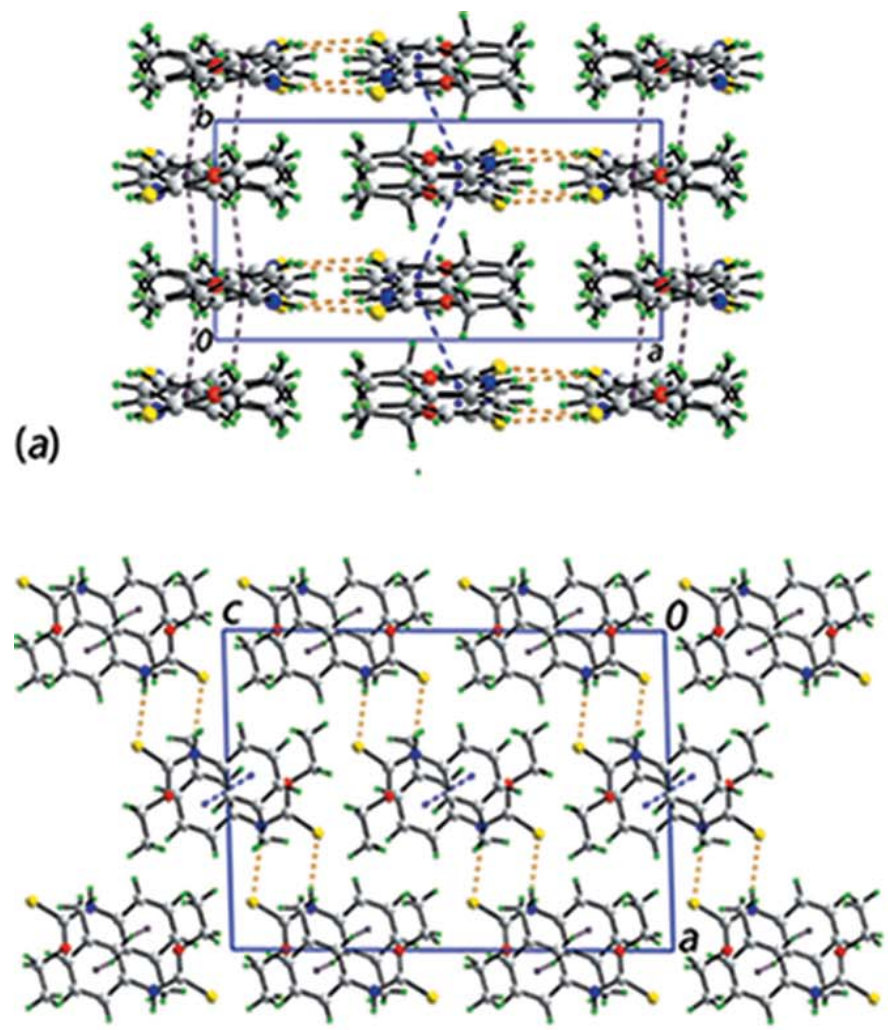

(b)

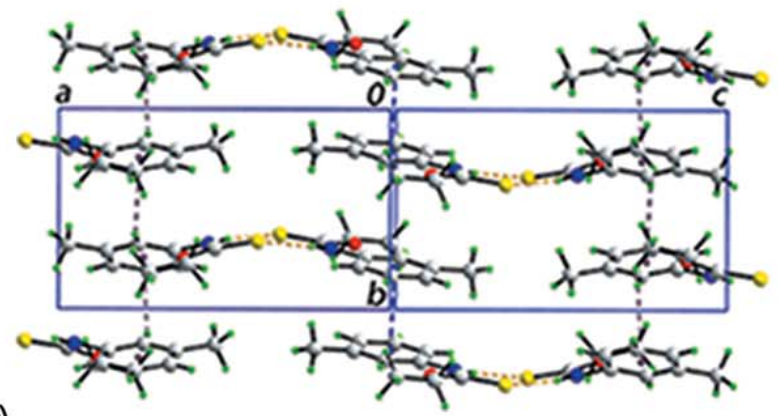

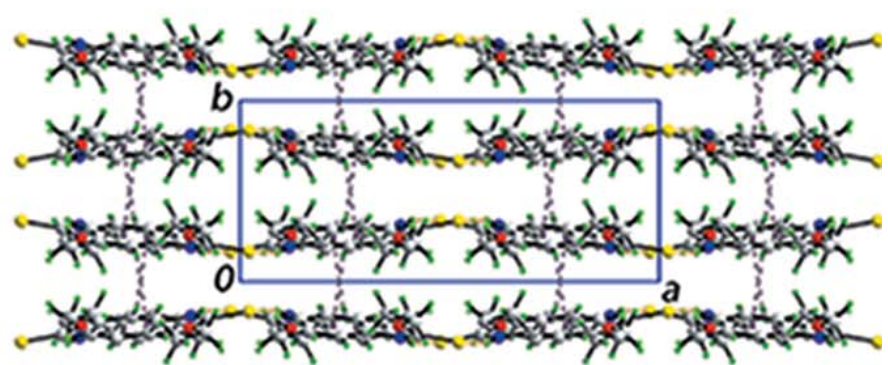

(d)

(e)

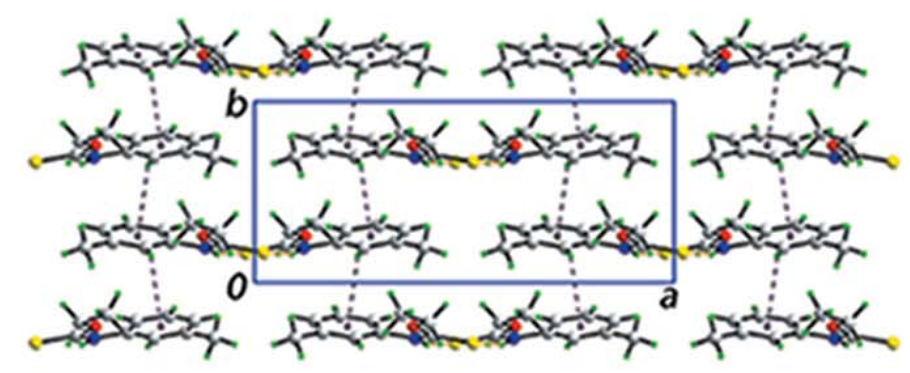

$(f)$

Figure 4

Molecular packing in (Ip): $(a)$ a view of the unit-cell contents shown in projection down the $c$ axis, $(b)$ a view of the unit-cell contents shown in projection down the $b$ axis and $(c)$ a view of the supramolecular layer. Molecular packing in (Ic): $(d)$ a view of the unit-cell contents shown in projection down the $c$ axis, $(e)$ a view of the unit-cell contents shown in projection down the $b$ axis and $(f)$ a view of the supramolecular layer. The thioamide- $\mathrm{N}-\mathrm{H} \cdots \mathrm{S}($ thione $)$, $\mathrm{C}-\mathrm{H} \cdots \pi$ and $\pi-\pi$ interactions are shown as orange, purple and blue dashed lines, respectively.

the intermolecular interactions instrumental in the crystals of the polymorphs.

The appearance of bright-red spots near the thioamide-H and thione-S atoms, diminutive red spots near the 3-tolyl-H, ethoxy-H atoms and thione-S atoms on the Hirshfeld surfaces mapped over $d_{\text {norm }}$ shown in Fig. 5 for both independent molecules of (Ip) as well as for polymorph (Ic) are indicative of comparable thioamide- $\mathrm{N}-\mathrm{H} \cdots \mathrm{S}$ (thione) and 3-tolyl-C$\mathrm{H} \cdots \mathrm{S}$ (thione) interactions, and short interatomic $\mathrm{H} \cdots \mathrm{H}$ contacts in their respective crystals, Table 4; values in Table 4 were obtained from an analysis employing the CrystalExplorer package (Wolff et al. 2012). As there are two independent molecules in monoclinic polymorph (Ip), it exhibits a pair of the above-mentioned intermolecular interactions shown with labels 1 to 4 in Fig. $5 a-c$, whereas in form (Ic) they are labelled as 1 and 2 in Fig. $5 d$ and $e$. In addition to the above, the faintred spots viewed near 3-tolyl-C14 in Fig. $5 b$ and ethoxy-H20B in Fig. $5 c$ indicate the significance of short interatomic $\mathrm{C} \cdots \mathrm{H} /$ $\mathrm{H}$. . C contacts, Table 4, in the packing of (Ip). The donors and acceptors of intermolecular interactions are also represented 
Table 4

Summary of short interatomic contacts $(\AA)$ in (Ip) and (Ic) ${ }^{a}$.

\begin{tabular}{|c|c|c|}
\hline Contact & Distance & Symmetry operation \\
\hline \multicolumn{3}{|l|}{ (Ip) } \\
\hline $\mathrm{H} 3 \cdots \mathrm{H} 14$ & 2.35 & $x, \frac{3}{2}-y,-\frac{1}{2}+z$ \\
\hline $\mathrm{H} 5 \cdots \mathrm{H} 9 B$ & 2.28 & $x, \frac{3}{2}-y, \frac{1}{2}+z$ \\
\hline $\mathrm{H} 15 \cdots \mathrm{H} 19 A$ & 2.31 & $x, \frac{3}{2}-y,-\frac{1}{2}+z$ \\
\hline H19B $\cdots \mathrm{H} 19 B$ & 2.08 & $2-x, 2-y, 1-z$ \\
\hline $\mathrm{C} 10 \cdots \mathrm{H} 20 C$ & 2.87 & $-1+x, y, z$ \\
\hline $\mathrm{C} 14 \cdots \mathrm{H} 20 B$ & 2.77 & $2-x,-\frac{1}{2}+y, \frac{1}{2}-z$ \\
\hline $\begin{array}{l}\mathrm{N} 1 \cdots \mathrm{H} 18 B \\
\text { (Ic) }\end{array}$ & 2.73 & $2-x,-\frac{1}{2}+y, \frac{1}{2}-z$ \\
\hline $\mathrm{H} 7 \cdots \mathrm{H} 9 b$ & 2.37 & $\frac{1}{2}+x, \frac{1}{2}-y, \frac{1}{2}+z$ \\
\hline $\mathrm{H} 9 a \cdots \mathrm{H} 9 a$ & 2.11 & $-x,-y,-z$ \\
\hline $\mathrm{H} 10 b \cdots \mathrm{H} 10 b$ & 2.32 & $\frac{1}{2}-x, \frac{1}{2}-y,-z$ \\
\hline
\end{tabular}

Note: (a) the atom numbering for the molecule in (Ic) follows that for the S1-molecule in (Ip).

with blue and red regions, respectively, on the Hirshfeld surfaces mapped over electrostatic potential in Fig. 6. The new monoclinic polymorph (Ip) has distinct and a greater number of short interatomic contacts than for (Ic) owing, in part, to the presence of two distinct molecules per asymmetric unit, Table 4. The short interatomic $\mathrm{H} \cdots \mathrm{H}$ contacts together with intermolecular $\mathrm{N}-\mathrm{H} \cdots \mathrm{S}$ and $\mathrm{C}-\mathrm{H} \cdots \mathrm{S}$ interactions formed with the atoms of reference molecules within Hirshfeld

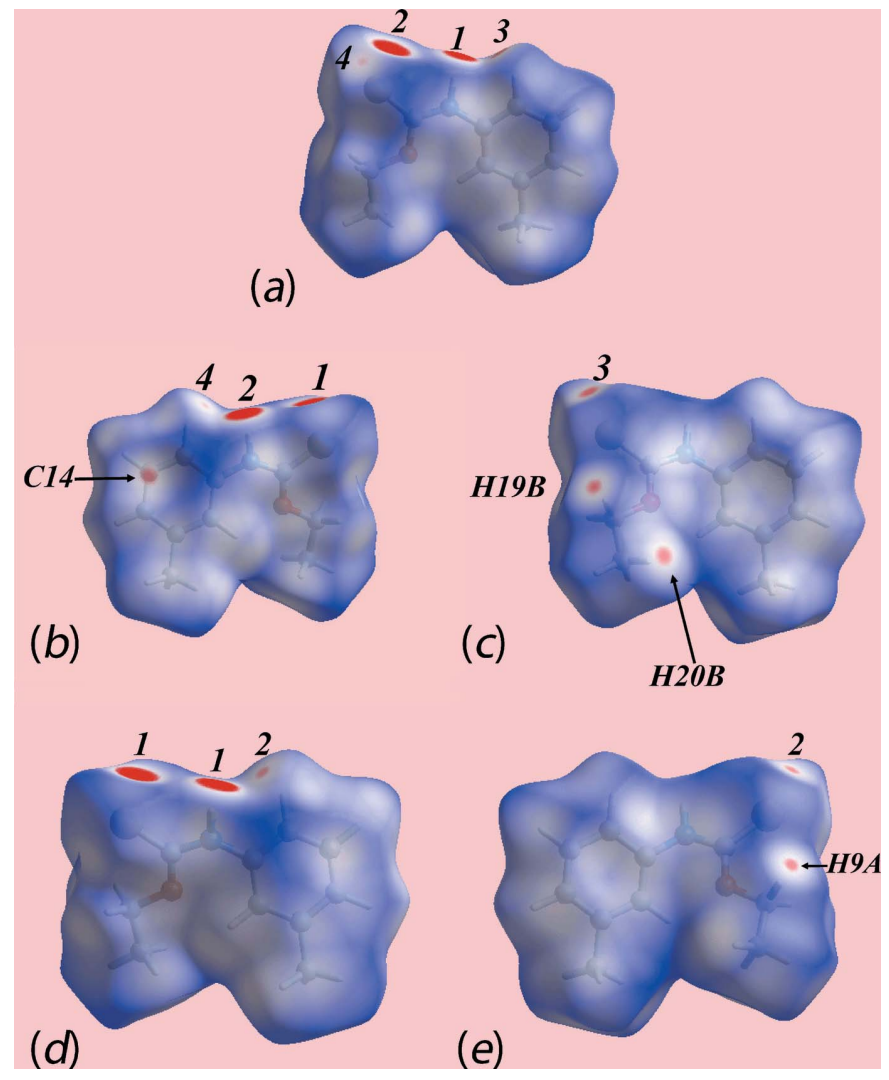

Figure 5

Views of the Hirshfeld surfaces mapped over $d_{\text {norm }}$ for the (a) S1containing molecule of (Ip) in the range -0.147 to $+1.345 \mathrm{au},(b)$ and $(c)$ S11-containing molecule in (Ip) in the range -0.149 to +1.274 au and $(d)$ and (e) molecule of polymorph (Ic) in the range -0.109 to $1.397 \mathrm{au}$.
Table 5

Percentage contributions of interatomic contacts to the Hirshfeld surfaces for the individual molecules in (Ip), overall (Ip) and (Ic).

\begin{tabular}{lllll}
\hline Contact & Percentage contribution & & \\
\hline & (Ip), S1-molecule & (Ip), S11-molecule & overall (Ip) & (Ic) \\
$\mathrm{H} \cdots \mathrm{H}$ & 57.4 & 55.5 & 61.7 & 57.0 \\
$\mathrm{~S} \cdots \mathrm{H} / \mathrm{H} \cdots \mathrm{S}$ & 17.6 & 17.4 & 10.0 & 17.3 \\
$\mathrm{C} \cdot \mathrm{H} / \mathrm{H} \cdots \mathrm{C}$ & 14.0 & 18.8 & 17.8 & 17.3 \\
$\mathrm{C} \cdots \mathrm{C}$ & 3.9 & 1.5 & 3.0 & 1.9 \\
$\mathrm{~N} \cdots \mathrm{H} / \mathrm{H} \cdots \mathrm{N}$ & 2.6 & 2.9 & 3.0 & 2.6 \\
$\mathrm{C} \cdots \mathrm{O} / \mathrm{O} \cdots \mathrm{C}$ & 2.5 & 2.5 & 2.7 & 2.4 \\
$\mathrm{O} \cdots \mathrm{H} / \mathrm{H} \cdots \mathrm{O}$ & 1.0 & 1.2 & 1.2 & 1.1 \\
$\mathrm{C} \cdots \mathrm{N} / \mathrm{N} \cdots \mathrm{C}$ & 0.9 & 0.3 & 0.6 & 0.4 \\
\hline
\end{tabular}

surfaces mapped over electrostatic potential for (Ip) and (Ic) are highlighted in Fig. 7.

The overall two-dimensional fingerprint plots for the S1 and S11-containing molecules of (Ip), the whole asymmetric unit of (Ip) and for the polymorph (Ic) are illustrated in Fig. $8 a-d$,
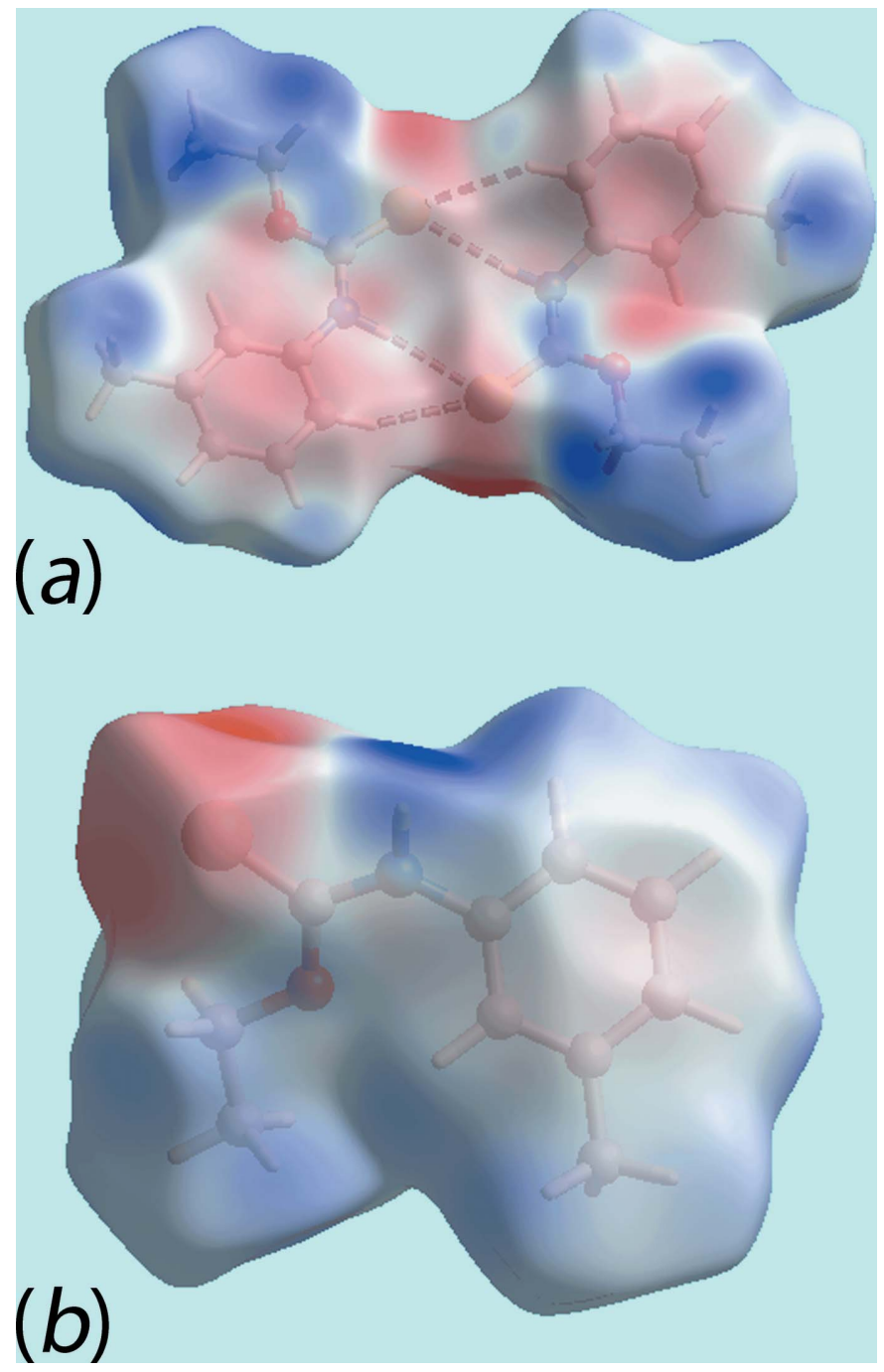

Figure 6

Views of Hirshfeld surfaces mapped over the electrostatic potential for (a) the asymmetric unit of (Ip) in the \pm 0.046 au range and (b) molecule of (Ic) in \pm 0.069 au range. The red and blue regions represent negative and positive electrostatic potentials, respectively. 


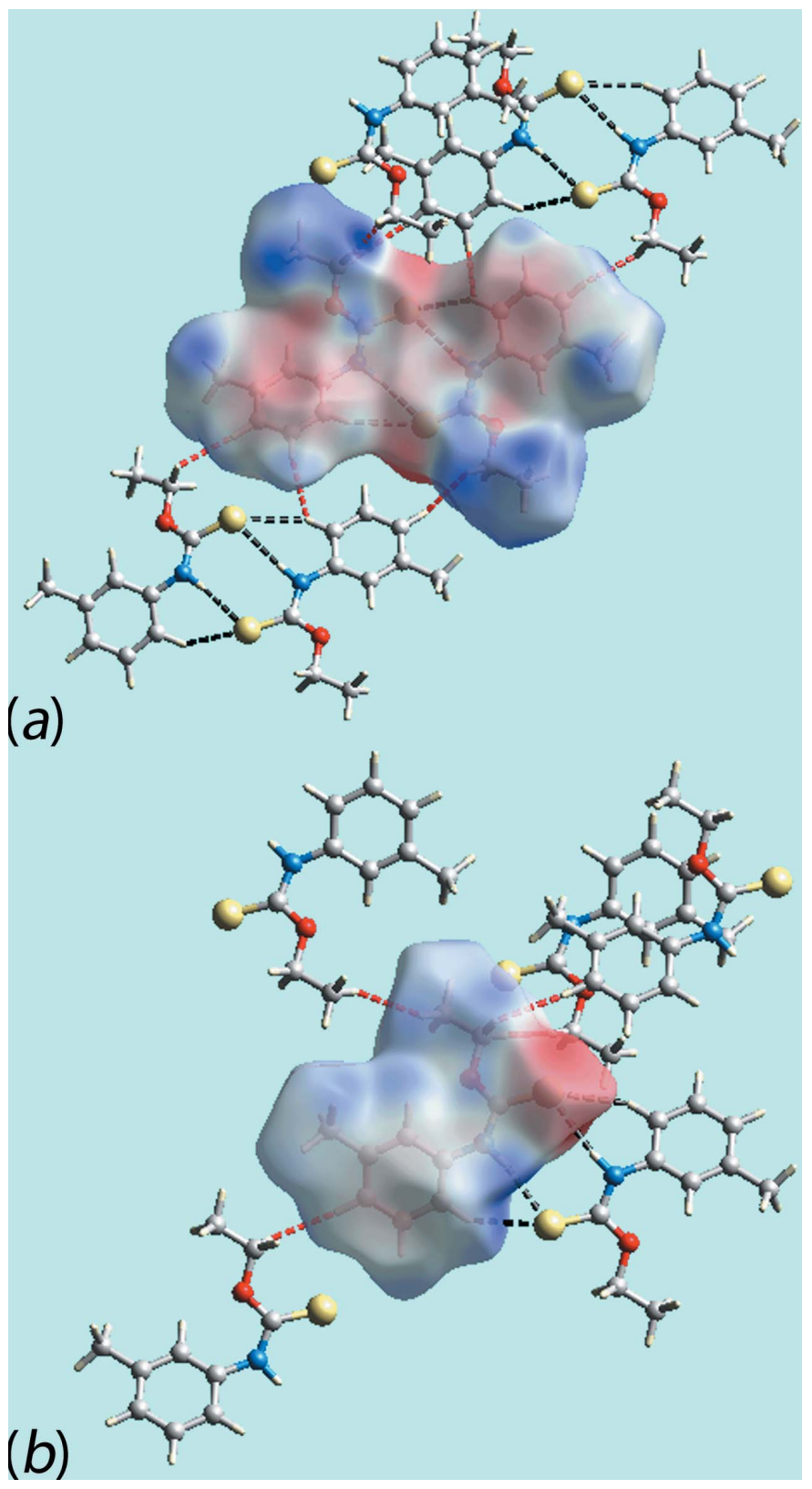

Figure 7

Views of the Hirshfeld surfaces about a reference molecule mapped over the electrostatic potential highlighting the short interatomic $\mathrm{H} \cdots \mathrm{H}$ contacts (red dashed lines) and intermolecular $\mathrm{N}-\mathrm{H} \cdots \mathrm{S}$ and $\mathrm{C}-\mathrm{H} \cdots \mathrm{S}$ interactions (black dashed lines) in ( $a$ ) (Ip) and (b) (Ic).

respectively. In addition, the fingerprint plots delineated into $\mathrm{H} \cdots \mathrm{H}, \mathrm{S} \cdots \mathrm{H} / \mathrm{H} \cdots \mathrm{S}, \mathrm{C} \cdots \mathrm{H} / \mathrm{H} \cdots \mathrm{C}, \mathrm{C} \cdots \mathrm{C}$ and $\mathrm{N} \cdots \mathrm{H} / \mathrm{H} \cdots \mathrm{N}$ contacts (McKinnon et al., 2007) are included in Fig. 8; the relative contributions from different interatomic contacts to the Hirshfeld surfaces are summarized in Table 5. The nearly similar distribution of points in the fingerprint plots for S11containing molecule of (Ip) and that of (Ic) indicate similarity in their molecular environments although some of the equivalent interatomic distances differ, Tables 2-4.

The fingerprint plots delineated into $\mathrm{H} \cdots \mathrm{H}$ contacts, Fig. $8 b$ and $d$, have needle-like tips pointing at $d_{\mathrm{e}}+d_{\mathrm{i}} \sim 2.1 \AA$ indicating short interatomic $\mathrm{H} \cdots \mathrm{H}$ contacts, Table 4, for the S11- containing molecule of (Ip) and for (Ic), both involving ethoxy-H atoms. The other short interatomic contacts in both forms are characterized from the points located within the pair of short peaks in (Ip) and a single short peak in (Ic), respectively, at $d_{\mathrm{e}}+d_{\mathrm{i}}<2.4 \AA$, i.e. at the sum of their van der Waals radii.

The involvement of ethoxy- $\mathrm{H}$ atoms in short interatomic C. $\cdot \mathrm{H} / \mathrm{H} \cdots \mathrm{C}$ contacts decreases the percentage contribution from $\mathrm{H} \cdots \mathrm{H}$ contacts to the Hirshfeld surface of the S11containing molecule whereas the contribution from equivalent contacts to the surface of the S1-containing molecule of (Ip) and that of (Ic) are almost same, Table 5. The increase in percentage contribution from these contacts to the Hirshfeld surface of overall asymmetric unit of (Ip) is due to the intermolecular $\mathrm{N}-\mathrm{H} \cdots \mathrm{S}$ and $\mathrm{C}-\mathrm{H} \cdots \mathrm{S}$ interactions between the respective atoms of S1- and S11-containing molecules thereby decreasing the contribution from $\mathrm{S} \cdot \mathrm{H} / \mathrm{H} \cdots \mathrm{S}$ contacts to the overall surface, Table 5 . This fact is confirmed from the nearly same percentage contribution from $\mathrm{S} \cdot \mathrm{H} / \mathrm{H} \cdots \mathrm{S}$ contacts to the Hirshfeld surfaces of the individual S1- and S11-containing molecules of (Ip) and of the molecule of the (Ic) form, Table 5, and also from pair of forceps-like tips at $d_{\mathrm{e}}+d_{\mathrm{i}} \sim 2.6 \AA$ with the nearly same distribution of points in their respective fingerprint plots in Fig. 8.

The similar distribution of points in the fingerprint plot delineated into $\mathrm{C} \cdots \mathrm{H} / \mathrm{H} \cdots \mathrm{C}$ contacts for the S11-containing molecule of (Ip), Fig. $8 b$, and of (Ic), Fig. $8 d$, indicate their involvement in the intermolecular $\mathrm{C}-\mathrm{H} \cdots \pi$ contacts showing pairs of tips at $d_{\mathrm{e}}+d_{\mathrm{i}} \sim 2.8$ and $2.9 \AA$, respectively. This is confirmed by the slight increase in the percentage contribution from these contacts to the Hirshfeld surface of the S11containing molecule of (Ip) $c f$. the S1-containing molecule, Table 5. In other words, the contribution from C $\cdots \mathrm{H} / \mathrm{H} \cdots \mathrm{C}$ contacts to the surface of the S1-containing molecule of (Ip), Table 5 , is decreased due to the absence of $\mathrm{C}-\mathrm{H} \cdots \pi$ contacts involving this molecule whereas the greater percentage contribution from C . . C contacts to the Hirshfeld surface of this molecule results from the presence of $\pi-\pi$ stacking interactions between the symmetry-related 3-tolyl rings. This is also evident from the arrow-like distribution of points around $d_{\mathrm{e}}=d_{\mathrm{i}}=1.8 \AA$ in the C $\cdots$ C delineated fingerprint plot shown in Fig. $8 a$.

The contribution of $3.0 \%$ from $\mathrm{N} \cdots \mathrm{H} / \mathrm{H} \cdots \mathrm{N}$ contacts to the Hirshfeld surface of whole asymmetric unit of polymorph (Ip) indicate the presence of short interatomic $\mathrm{N} \cdots \mathrm{H} / \mathrm{H} \cdots \mathrm{N}$ contacts between the thioamide-N1 and tolyl-H18B atoms, Table 4, although all of the delineated fingerprint plots have a similar distributions of points, Fig. 8, at least to a first approximation. The other interatomic contacts summarized in Table 4 make only small contributions to the Hirshfeld surfaces and have negligible contributions on the respective molecular packings.

\section{Database survey}

According to a search of the Cambridge Structural Database (Version 5.38, May update; Groom et al., 2016), there are 22 
Table 6

Hydrogen-bonding patterns in $R \mathrm{OC}(=\mathrm{S}) \mathrm{N}(\mathrm{H}) R^{\prime}$.

\begin{tabular}{|c|c|c|c|c|c|c|c|}
\hline Number & $R$ & $R^{\prime}$ & $Z^{\prime}$ & Hydrogen bonds & Motif & Refcode & Ref. \\
\hline (II) & $\mathrm{Me}$ & phenyl & 1 & $\mathrm{~N}-\mathrm{H} \cdots \mathrm{S}$ & $\mathbf{A}$ & OJIHAQ & Ho et al. (2003) \\
\hline (III) & $\mathrm{Me}$ & 4-NO $\mathrm{NO}_{2}$-phenyl & 1 & $\mathrm{~N}-\mathrm{H} \cdots \mathrm{S}$ & $\mathbf{A}$ & CAZFUF & Ho et al. (2005) \\
\hline (IV) & $\mathrm{Me}$ & 4- $C(=\mathrm{O})$ OMe-phenyl & 1 & $\mathrm{~N}-\mathrm{H} \cdots \mathrm{S}$ & $\mathbf{A}$ & CAZGAM & Ho et al. (2005) \\
\hline (VI) & $\mathrm{Me}$ & 4- $C(=\mathrm{O}) \mathrm{Me}$-phenyl & 1 & $\mathrm{~N}-\mathrm{H} \cdots \mathrm{O}$ & B & CAZGIU & Ho et al. (2005) \\
\hline (VII) & $\mathrm{Me}$ & 2-tolyl & 1 & $\mathrm{~N}-\mathrm{H} \cdots \mathrm{S}$ & $\mathbf{A}$ & TAZSIX & Kuan et al. (2005) \\
\hline (VIII) & $\mathrm{Me}$ & 4-tolyl & 2 & $\mathrm{~N}-\mathrm{H} \cdots \mathrm{S}$ & $\mathbf{A}^{\prime}$ & TIBYUZ & Ho et al. (2007) \\
\hline (IX) & Et & phenyl & 3 & $\mathrm{~N}-\mathrm{H} \cdots \mathrm{S}$ & $\mathbf{A}^{\prime \prime}$ & PINPIL & Taylor \& Tiekink (1994) \\
\hline$(X)$ & Et & 4-tolyl & 1 & $\mathrm{~N}-\mathrm{H} \cdots \mathrm{S}$ & $\mathbf{A}$ & TIBYOT & Tadbuppa \& Tiekink (2007a) \\
\hline (XI) & Et & 3-OMe-phenyl & 1 & $\mathrm{~N}-\mathrm{H} \cdots \mathrm{S}$ & $\mathbf{A}$ & UDUPAL & Hanif et al. (2007) \\
\hline (XII) & Et & 4- $\mathrm{NO}_{2}$-phenyl & 1 & $\mathrm{~N}-\mathrm{H} \cdots \mathrm{S}$ & $\mathbf{A}$ & NENLAU & Benson et al. (2006) \\
\hline (XIII) & Et & 4-Cl-phenyl & 1 & $\mathrm{~N}-\mathrm{H} \cdots \mathrm{S}$ & $\mathbf{A}$ & DEYQEE & Tadbuppa \& Tiekink $(2007 b)$ \\
\hline (XIV) & $n-\operatorname{Pr}$ & phenyl & 2 & $\mathrm{~N}-\mathrm{H} \cdots \mathrm{S}$ & $\mathbf{A}^{\prime}$ & PAWKAB & Sudkaow et al. (2012) \\
\hline$(\mathrm{XV})$ & $i-\operatorname{Pr}$ & $\mathrm{Ph}$ & 1 & $\mathrm{~N}-\mathrm{H} \cdots \mathrm{S}$ & $\mathbf{A}$ & ADOGUW & Kuan et al. (2007) \\
\hline$(\mathrm{XVI})$ & $i-\operatorname{Pr}$ & 4-tolyl & 1 & $\mathrm{~N}-\mathrm{H} \cdots \mathrm{S}$ & $\mathbf{A}$ & ADOGOQ & Kuan et al. (2007) \\
\hline$(\mathrm{XXI})$ & 2,4- $\mathrm{Me}_{2}$-phenyl & phenyl & 1 & $\mathrm{~N}-\mathrm{H} \cdots \mathrm{S}$ & $\mathbf{A}$ & POVVOL & Abraham et al. (1995) \\
\hline (XXII) & 2,4-(OMe $)_{2}$-phenyl & $R^{1 a}$ & 1 & $\mathrm{~N}-\mathrm{H} \cdots \mathrm{N}$ & C & OSIZOG & Zhou et al. (2010) \\
\hline (XXIII) & $\mathrm{Cy}$ & phenyl & 2 & $\mathrm{~N}-\mathrm{H} \cdots \mathrm{S}$ & $\mathbf{A}^{\prime}$ & VEFKUO & Sahoo et al. (2012) \\
\hline
\end{tabular}

Note: (a) see Scheme 2 for the chemical diagram of (XXII).

(a)
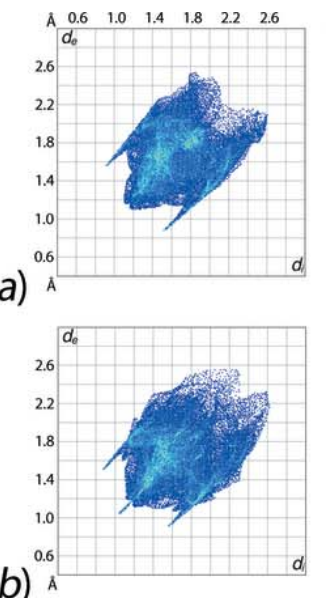

(b) $\AA$

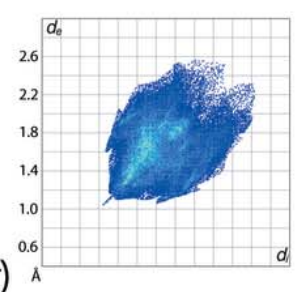

(c)

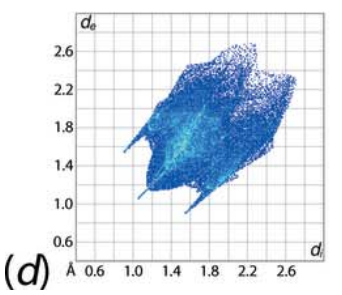

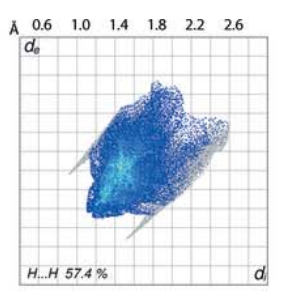
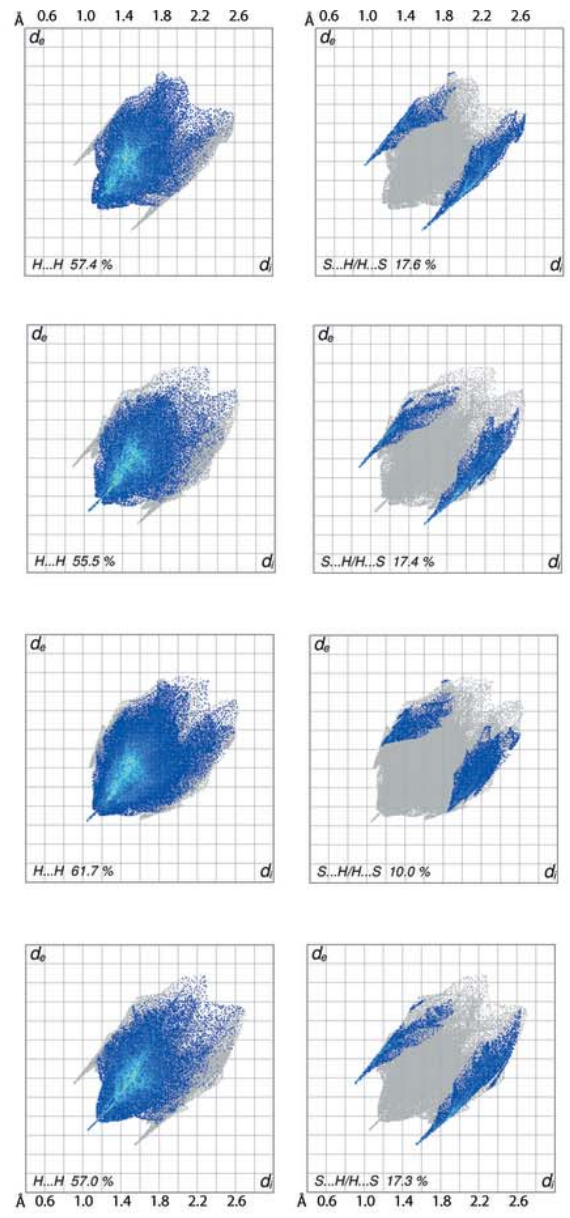
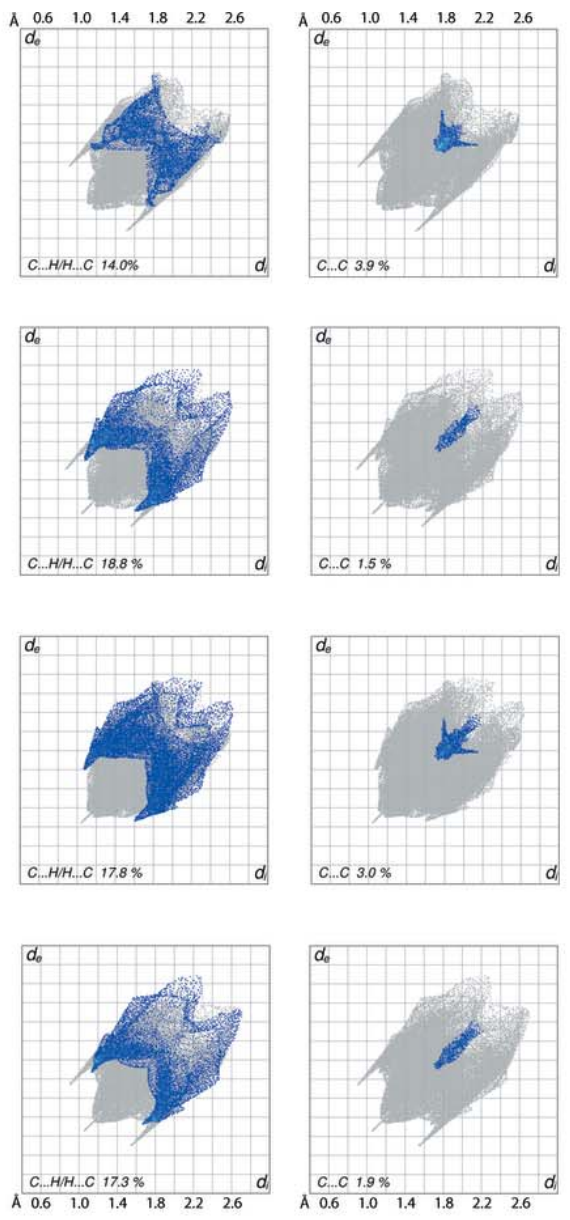
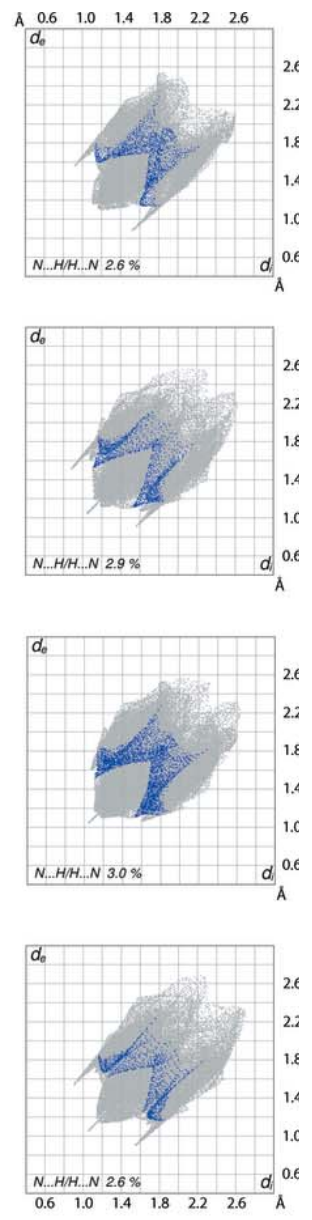

Figure 8

The full two-dimensional fingerprint plot and those delineated into $\mathrm{H} \cdots \mathrm{H}, \mathrm{S} \cdots \mathrm{H} / \mathrm{H} \cdots \mathrm{S}, \mathrm{C} \cdots \mathrm{H} / \mathrm{H} \cdots \mathrm{C}, \mathrm{C} \cdots \mathrm{C}$ and $\mathrm{N} \cdots \mathrm{H} / \mathrm{H} \cdots \mathrm{N}($ left to right) contacts for (a) S1-molecule of (Ip), (b) S11-molecule of (Ip), (c) overall (Ip) and (d) (Ic). 
(a)

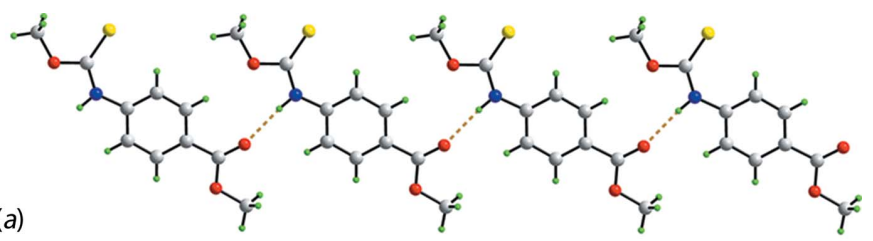

(b)

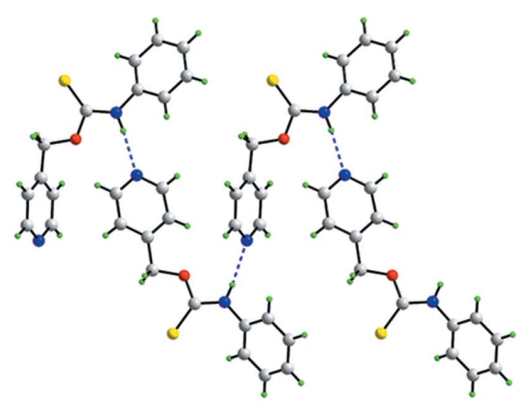

Figure 9

Supramolecular aggregation in related carbothioamide structures: $(a)$ linear supramolecular chain in the crystal of $\mathrm{MeOC}(=\mathrm{S}) \mathrm{N}(\mathrm{H})(4-$ $\mathrm{C}(=\mathrm{O})$ Me-phenyl $)(\mathrm{VI})$ mediated by thioamide- $\mathrm{N}-\mathrm{H} \cdots \mathrm{O}$ (carboxy) hydrogen bonding shown as orange dashed lines and $(b)$ zigzag chain in the crystal of (4-pyridyl) $\mathrm{CH}_{2} \mathrm{OC}(=\mathrm{S}) \mathrm{N}(\mathrm{H})$ phenyl mediated by thioamide- $\mathrm{N}-\mathrm{H} \cdots \mathrm{N}$ (pyridyl) hydrogen bonding shown as blue dashed lines.

monofunctional carbothioamide molecules related to the title compound, with (Ip) and (Ic) being the only pair of polymorphs characterized thus far. Referring to Table 6, the overwhelming majority of the 24 crystallographically characterized thioamides feature an eight-membered thioamide, $\{\cdots \mathrm{SCNH}\}_{2}$, synthon. Thus, in 13 of the characterized structures, the synthon is formed about a centre of inversion, motif A. In five structures, two independent molecules $\left(Z^{\prime}=2\right)$ comprise the asymmetric unit, as in (Ip), and these associated via the $\{\cdots \mathrm{SCNH}\}_{2}$ synthon but with no crystallographically imposed symmetry, motif $\mathbf{A}^{\prime}$. There is a single example of a structure with $Z^{\prime}=3$ (Taylor \& Tiekink, 1994). Here, one of the independent molecules self-associates about a centre of inversion, as in motif $\mathbf{A}$, whereas the two remaining independent molecules are connected by the $\{\cdots \mathrm{SCNH}\}_{2}$ synthon, as found in motif $\mathbf{A}^{\prime}$. This is motif $\mathbf{A}^{\prime \prime}$. Two structures feature the $\{\cdots \mathrm{SCNH}\}_{2}$ synthon located about a twofold axis of symmetry, as in (Ic), i.e. motif $\mathbf{A}^{\prime \prime \prime}$. The remaining three structures do not feature thioamide- $\mathrm{N}-\mathrm{H} \cdots \mathrm{S}$ (thione) hydrogen bonding. In the structure of $\mathrm{MeOC}(=\mathrm{S}) \mathrm{N}(\mathrm{H})(4-$ $\mathrm{C}(=\mathrm{O}) \mathrm{Me}$-phenyl) (VI) (Ho et al., 2005), motif B, thioamide$\mathrm{N}-\mathrm{H} \cdots \mathrm{O}$ (carboxy) hydrogen bonding is observed, leading to a linear supramolecular chain as shown in Fig. 9a. This structure is noteworthy as being the only example where the conformation of the thioamide moiety is anti rather than the normally observed syn. The final variation, motif $\mathbf{C}$, is found in two structures, Table 6. The structure of (4-pyridyl)$\mathrm{CH}_{2} \mathrm{OC}(=\mathrm{S}) \mathrm{N}(\mathrm{H})$ phenyl (XIX) (Xiao et al., 2006) serves as an exemplar. Thus, in the crystal of (XIX), thioamide-N$\mathrm{H} \cdots \mathrm{N}$ (pyridyl) hydrogen bonds lead to a zigzag chain as shown in Fig. 9b. In summary, an inspection of the data in Table 6 indicates the predominance of thioamide- $\mathrm{N}-$
Table 7

Experimental details.

\begin{tabular}{|c|c|}
\hline \multicolumn{2}{|l|}{ Crystal data } \\
\hline Chemical formula & $\mathrm{C}_{10} \mathrm{H}_{13} \mathrm{NOS}$ \\
\hline$M_{\mathrm{r}}$ & 195.27 \\
\hline Crystal system, space group & Monoclinic, $P 2_{1} / c$ \\
\hline Temperature $(\mathrm{K})$ & 100 \\
\hline$a, b, c(\AA)$ & $14.3999(5), 7.0388(3), 19.9725$ (7) \\
\hline$\beta\left({ }^{\circ}\right)$ & $91.727(3)$ \\
\hline$V\left(\mathrm{~A}^{6}\right)$ & $2023.45(13)$ \\
\hline$Z$ & 8 \\
\hline Radiation type & Мo $K \alpha$ \\
\hline$\mu\left(\mathrm{mm}^{-1}\right)$ & 0.28 \\
\hline Crystal size $(\mathrm{mm})$ & $0.20 \times 0.20 \times 0.05$ \\
\hline \multicolumn{2}{|l|}{ Data collection } \\
\hline Diffractometer & $\begin{array}{l}\text { Agilent SuperNova, Dual, Mo at } \\
\text { zero, Atlas }\end{array}$ \\
\hline Absorption correction & $\begin{array}{l}\text { Multi-scan (CrysAlis PRO; } \\
\quad \text { Agilent, 2011) }\end{array}$ \\
\hline$T_{\min }, T_{\max }$ & $0.662,1.000$ \\
\hline $\begin{array}{l}\text { No. of measured, independent and } \\
\text { observed }[I>2 \sigma(I)] \text { reflections }\end{array}$ & $15588,4577,3514$ \\
\hline & 0.040 \\
\hline$(\sin \theta / \lambda)_{\max }\left(\AA^{-1}\right)$ & 0.651 \\
\hline \multicolumn{2}{|l|}{ Refinement } \\
\hline$R\left[F^{2}>2 \sigma\left(F^{2}\right)\right], w R\left(F^{2}\right), S$ & $0.047,0.125,1.03$ \\
\hline No. of reflections & 4577 \\
\hline No. of parameters & 245 \\
\hline No. of restraints & 2 \\
\hline H-atom treatment & $\begin{array}{l}\mathrm{H} \text { atoms treated by a mixture of } \\
\text { independent and constrained } \\
\text { refinement }\end{array}$ \\
\hline$\Delta \rho_{\max }, \Delta \rho_{\min }\left(\mathrm{e} \AA^{-3}\right)$ & $0.72,-0.24$ \\
\hline
\end{tabular}

Computer programs: CrysAlis PRO (Agilent, 2011), SHELXS97 (Sheldrick, 2008), SHELXL2014 (Sheldrick, 2015), ORTEP-3 for Windows (Farrugia, 2012), QMol (Gans \& Shalloway, 2001), DIAMOND (Brandenburg, 2006) and publCIF (Westrip, 2010).

$\mathrm{H}$...S(thione) hydrogen bonding in these carbothioamides, at least in the absence of competing synthons, as seen in motifs $\mathbf{B}$ and $\mathbf{C}$

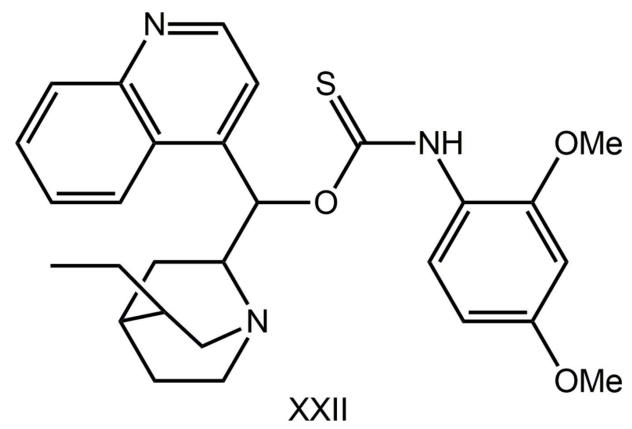

\section{Synthesis and crystallization}

All chemicals and solvents were used as purchased without purification. To prepare (Ip), 3-tolyl isothiocyanate (Merck; $2.5 \mathrm{mmol}, 0.34 \mathrm{ml}$ ) was added to $\mathrm{NaOH}$ (Merck; $2.5 \mathrm{mmol}$, $0.10 \mathrm{~g}$ ) in EtOH (Merck; $3 \mathrm{ml}$ ) and the mixture was stirred at room temperature for $2 \mathrm{~h}$, followed by the addition of excess $5 \mathrm{M} \mathrm{HCl}$ solution. The resulting mixture was stirred for another $1.5 \mathrm{~h}$. The final product was extracted with chloroform (Merck; $10 \mathrm{ml}$ ) and left for evaporation at room temperature, 
yielding brown crystals after 1 week. M.p. (Krüss KSP1N melting point meter): 339-340 K. IR (Perkin Elmer Spectrum 400 FT Mid-IR/Far-IR spectrophotometer; $\left.\mathrm{cm}^{-1}\right)$ : $3211(\mathrm{~s})$ $(\mathrm{N}-\mathrm{H}), 1451(s)(\mathrm{C}-\mathrm{N}), 1209(s)(\mathrm{C}=\mathrm{S}), 1064(s)(\mathrm{C}-\mathrm{O})$.

\section{Refinement}

Crystal data, data collection and structure refinement details are summarized in Table 7. The carbon-bound $\mathrm{H}$ atoms were placed in calculated positions $(\mathrm{C}-\mathrm{H}=0.95-0.99 \AA)$ and were included in the refinement in the riding-model approximation, with $U_{\text {iso }}(\mathrm{H})$ set to $1.2-1.5 U_{\text {eq }}(\mathrm{C})$. The nitrogen-bound $\mathrm{H}$ atoms were located in a difference Fourier map but were refined with a distance restraint of $\mathrm{N}-\mathrm{H}=0.88 \pm 0.01 \AA$, and with $U_{\text {iso }}(\mathrm{H})$ set to $1.2 U_{\text {eq }}(\mathrm{N})$. Owing to poor agreement, one reflection, i.e. ( $\overline{15} 14)$, was omitted from the final cycles of refinement.

\section{Acknowledgements}

The authors thank the staff of the University of Malaya's $\mathrm{X}$-ray diffraction laboratory for the data collection. Sunway University is thanked for support of biological and crystal engineering studies of carbothioamides and their coinage metal complexes.

\section{References}

Abraham, S. P., Samuelson, A. G. \& Nethaji, M. (1995). Proc. Indian Acad. Sci. Chem. Sci. 107, 255-271.

Agilent (2011). CrysAlis PRO. Agilent Technologies, Yarnton, England.

Benson, R. E., Broker, G. A., Daniels, L. M., Tiekink, E. R. T., Wardell, J. L. \& Young, D. J. (2006). Acta Cryst. E62, o4106-04108.

Brandenburg, K. (2006). DIAMOND. Crystal Impact GbR, Bonn, Germany.

Ellis, C. A., Miller, M. A., Spencer, J., Zukerman-Schpector, J. \& Tiekink, E. R. T. (2009). CrystEngComm, 11, 1352-1361.

Ellis, C. A., Tiekink, E. R. T. \& Zukerman-Schpector, J. (2008). Acta Cryst. E64, o345.

Farrugia, L. J. (2012). J. Appl. Cryst. 45, 849-854.

Gans, J. \& Shalloway, D. (2001). J. Mol. Graph. Model. 19, 557-609.

Groom, C. R., Bruno, I. J., Lightfoot, M. P. \& Ward, S. C. (2016). Acta Cryst. B72, 171-179.

Hanif, M., Qadeer, G., Shi, L. \& Rama, N. H. (2007). Acta Cryst. E63, 03062.

Ho, S. Y., Bettens, R. P. A., Dakternieks, D., Duthie, A. \& Tiekink, E. R. T. (2005). CrystEngComm, 7, 682-689.
Ho, S. Y., Cheng, E. C.-C., Tiekink, E. R. T. \& Yam, V. W.-W. (2006). Inorg. Chem. 45, 8165-8174.

Ho, S. Y., Kuan, F. S. \& Tiekink, E. R. T. (2007). Acta Cryst. E63, o1723-o1724.

Ho, S. Y., Lai, C. S. \& Tiekink, E. R. T. (2003). Acta Cryst. E59, o1155o1156.

Jian, F.-F., Yu, H.-Q., Qiao, Y.-B. \& Liang, T.-L. (2006). Acta Cryst. E62, o3416-03417.

Kuan, F. S., Jotani, M. M. \& Tiekink, E. R. T. (2017). Acta Cryst. E73, $1465-1471$.

Kuan, F. S., Mohr, F., Tadbuppa, P. P. \& Tiekink, E. R. T. (2007). CrystEngComm, 9, 574-581.

Kuan, F. S., Tadbuppa, P. P. \& Tiekink, E. R. T. (2005). Z. Kristallogr. New Cryst. Struct. 220, 393-394.

McKinnon, J. J., Jayatilaka, D. \& Spackman, M. A. (2007). Chem. Commun. pp. 3814-3816.

Ooi, K. K., Yeo, C. I., Mahandaran, T., Ang, K. P., Akim, A. M., Cheah, Y.-K., Seng, H.-L. \& Tiekink, E. R. T. (2017). J. Inorg. Biochem. 166, 173-181.

Sahoo, S. K., Chakraborty, S. \& Patel, B. K. (2012). J. Sulfur Chem. 33, 143-153.

Sheldrick, G. M. (2008). Acta Cryst. A64, 112-122.

Sheldrick, G. M. (2015). Acta Cryst. C71, 3-8.

Slater, N. H., Buckley, B. R., Elsegood, M. R. J., Teat, S. J. \& Kimber, M. C. (2016). Cryst. Growth Des. 16, 3846-3852.

Spek, A. L. (2009). Acta Cryst. D65, 148-155.

Sudkaow, P., Yeo, C. I., Ng, S. W. \& Tiekink, E. R. T. (2012). Acta Cryst. E68, o1774.

Tadbuppa, P. P. \& Tiekink, E. R. T. (2005). Z. Kristallogr. New Cryst. Struct. 220, 395-396.

Tadbuppa, P. P. \& Tiekink, E. R. T. (2007a). Acta Cryst. E63, o1779o1780.

Tadbuppa, P. P. \& Tiekink, E. R. T. (2007b). Acta Cryst. E63, o1885o1886.

Taylor, R. L. \& Tiekink, E. R. T. (1994). Z. Kristallogr. 209, 64-67.

Westrip, S. P. (2010). J. Appl. Cryst. 43, 920-925.

Wolff, S. K., Grimwood, D. J., McKinnon, J. J., Turner, M. J., Jayatilaka, D. \& Spackman, M. A. (2012). University of Western Australia.

Xiao, H.-L., Wang, K.-F. \& Jian, F.-F. (2006). Acta Cryst. E62, o2852o2853.

Yeo, C. I., Halim, S. N. A., Ng, S. W., Tan, S. L., Zukerman-Schpector, J., Ferreira, M. A. B. \& Tiekink, E. R. T. (2014). Chem. Commun. 50, 5984-5986.

Yeo, C. I., Sim, J.-H., Khoo, C.-H., Goh, Z.-J., Ang, K.-P., Cheah, Y.-K., Fairuz, Z. A., Halim, S. N. B. A., Ng, S. W., Seng, H.-L. \& Tiekink, E. R. T. (2013). Gold Bull. 46, 145-152.

Zhou, L., Tan, C. K., Jiang, X., Chen, F. \& Yeung, Y.-Y. (2010). J. Am. Chem. Soc. 132, 15474-15476.

Zukerman-Schpector, J., Yeo, C. I. \& Tiekink, E. R. T. (2016). Z. Kristallogr. 231, 55-64. 


\section{supporting information}

Acta Cryst. (2017). E73, 1889-1897 [https://doi.org/10.1107/S2056989017016280]

\section{A new monoclinic polymorph of $\mathrm{N}$-(3-methylphenyl)ethoxycarbothioamide:}

\section{crystal structure and Hirshfeld surface analysis}

\section{Mukesh M. Jotani, Chien Ing Yeo and Edward R. T. Tiekink}

Computing details

Data collection: CrysAlis PRO (Agilent, 2011); cell refinement: CrysAlis PRO (Agilent, 2011); data reduction: CrysAlis PRO (Agilent, 2011); program(s) used to solve structure: SHELXS97 (Sheldrick, 2008); program(s) used to refine structure: SHELXL2014 (Sheldrick, 2015); molecular graphics: ORTEP-3 for Windows (Farrugia, 2012), QMol (Gans \& Shalloway, 2001) and DIAMOND (Brandenburg, 2006); software used to prepare material for publication: publCIF (Westrip, 2010).

$N$-(3-Methylphenyl)ethoxycarbothioamide

Crystal data

$\mathrm{C}_{10} \mathrm{H}_{13} \mathrm{NOS}$

$M_{r}=195.27$

Monoclinic, $P 2_{1} / c$

$a=14.3999(5) \AA$

$b=7.0388(3) \AA$

$c=19.9725$ (7) $\AA$

$\beta=91.727(3)^{\circ}$

$V=2023.45(13) \AA^{3}$

$Z=8$

Data collection

Agilent SuperNova, Dual, Mo at zero, Atlas diffractometer

Radiation source: SuperNova (Mo) X-ray

Source

Mirror monochromator

Detector resolution: 10.4041 pixels $\mathrm{mm}^{-1}$

$\omega$ scan

Absorption correction: multi-scan

(CrysAlis PRO; Agilent, 2011)

\section{Refinement}

Refinement on $F^{2}$

Least-squares matrix: full

$R\left[F^{2}>2 \sigma\left(F^{2}\right)\right]=0.047$

$w R\left(F^{2}\right)=0.125$

$S=1.03$

4577 reflections

245 parameters

2 restraints
$F(000)=832$

$D_{\mathrm{x}}=1.282 \mathrm{Mg} \mathrm{m}^{-3}$

Mo $K \alpha$ radiation, $\lambda=0.71073 \AA$

Cell parameters from 6144 reflections

$\theta=2.4-27.5^{\circ}$

$\mu=0.28 \mathrm{~mm}^{-1}$

$T=100 \mathrm{~K}$

Slab, colourless

$0.20 \times 0.20 \times 0.05 \mathrm{~mm}$

$T_{\min }=0.662, T_{\max }=1.000$

15588 measured reflections

4577 independent reflections

3514 reflections with $I>2 \sigma(I)$

$R_{\text {int }}=0.040$

$\theta_{\text {max }}=27.6^{\circ}, \theta_{\min }=2.5^{\circ}$

$h=-18 \rightarrow 18$

$k=-9 \rightarrow 9$

$l=-18 \rightarrow 25$

$\mathrm{H}$ atoms treated by a mixture of independent and constrained refinement

$w=1 /\left[\sigma^{2}\left(F_{\mathrm{o}}^{2}\right)+(0.0629 P)^{2}+0.8006 P\right]$

where $P=\left(F_{\mathrm{o}}^{2}+2 F_{\mathrm{c}}^{2}\right) / 3$

$(\Delta / \sigma)_{\max }=0.001$

$\Delta \rho_{\max }=0.72$ e $\AA^{-3}$

$\Delta \rho_{\min }=-0.24$ e $\AA^{-3}$ 


\section{Special details}

Geometry. All esds (except the esd in the dihedral angle between two 1.s. planes) are estimated using the full covariance matrix. The cell esds are taken into account individually in the estimation of esds in distances, angles and torsion angles; correlations between esds in cell parameters are only used when they are defined by crystal symmetry. An approximate (isotropic) treatment of cell esds is used for estimating esds involving l.s. planes.

Fractional atomic coordinates and isotropic or equivalent isotropic displacement parameters $\left(\AA^{2}\right)$

\begin{tabular}{|c|c|c|c|c|}
\hline & $x$ & $y$ & $z$ & $U_{\text {iso }} * / U_{\text {eq }}$ \\
\hline S1 & $0.63595(3)$ & $0.62560(8)$ & $0.29847(2)$ & $0.02560(15)$ \\
\hline $\mathrm{O} 1$ & $0.48087(9)$ & $0.6728(2)$ & $0.36508(7)$ & $0.0205(3)$ \\
\hline N1 & $0.61175(11)$ & $0.6959(2)$ & $0.42674(8)$ & $0.0176(3)$ \\
\hline $\mathrm{H} 1 \mathrm{~N}$ & $0.6720(7)$ & $0.683(3)$ & $0.4295(11)$ & $0.021^{*}$ \\
\hline $\mathrm{C} 1$ & $0.57256(13)$ & $0.6663(3)$ & $0.36605(10)$ & $0.0183(4)$ \\
\hline $\mathrm{C} 2$ & $0.57411(12)$ & $0.7410(3)$ & $0.48972(9)$ & $0.0157(4)$ \\
\hline $\mathrm{C} 3$ & $0.63901(13)$ & $0.7851(3)$ & $0.54059(10)$ & $0.0198(4)$ \\
\hline $\mathrm{H} 3$ & 0.7035 & 0.7828 & 0.5318 & $0.024 *$ \\
\hline $\mathrm{C} 4$ & $0.60988(14)$ & $0.8320(3)$ & $0.60359(10)$ & $0.0224(4)$ \\
\hline $\mathrm{H} 4$ & 0.6545 & 0.8604 & 0.6382 & $0.027 *$ \\
\hline $\mathrm{C} 5$ & $0.51590(14)$ & $0.8380(3)$ & $0.61691(10)$ & $0.0214(4)$ \\
\hline H5 & 0.4963 & 0.8719 & 0.6603 & $0.026^{*}$ \\
\hline $\mathrm{C} 6$ & $0.45044(13)$ & $0.7944(3)$ & $0.56662(10)$ & $0.0189(4)$ \\
\hline $\mathrm{C} 7$ & $0.47948(13)$ & 0.7455 & $0.50316(10)$ & $0.0185(4)$ \\
\hline $\mathrm{H} 7$ & 0.4349 & 0.7151 & 0.4688 & $0.022^{*}$ \\
\hline $\mathrm{C} 8$ & $0.34802(13)$ & $0.8043(3)$ & $0.58036(11)$ & $0.0258(5)$ \\
\hline H8A & 0.3157 & 0.6989 & 0.5576 & $0.039^{*}$ \\
\hline H8B & 0.3227 & 0.9252 & 0.5637 & $0.039^{*}$ \\
\hline $\mathrm{H} 8 \mathrm{C}$ & 0.3391 & 0.7952 & 0.6287 & $0.039^{*}$ \\
\hline C9 & $0.43042(14)$ & $0.6465(3)$ & $0.30146(10)$ & $0.0250(5)$ \\
\hline H9A & 0.4433 & 0.5193 & 0.2827 & $0.030^{*}$ \\
\hline H9B & 0.4489 & 0.7440 & 0.2687 & $0.030^{*}$ \\
\hline $\mathrm{C} 10$ & $0.33069(15)$ & $0.6655(4)$ & $0.31611(12)$ & $0.0334(5)$ \\
\hline $\mathrm{H} 10 \mathrm{~A}$ & 0.2934 & 0.6493 & 0.2747 & $0.050^{*}$ \\
\hline $\mathrm{H} 10 \mathrm{~B}$ & 0.3192 & 0.7917 & 0.3349 & $0.050^{*}$ \\
\hline $\mathrm{H} 10 \mathrm{C}$ & 0.3135 & 0.5680 & 0.3485 & $0.050^{*}$ \\
\hline S11 & $0.85195(3)$ & $0.66025(9)$ & $0.45041(2)$ & $0.02577(15)$ \\
\hline O11 & $0.99877(9)$ & $0.7448(2)$ & $0.37829(6)$ & $0.0192(3)$ \\
\hline N11 & $0.86976(10)$ & $0.6753(2)$ & $0.31952(8)$ & $0.0175(3)$ \\
\hline $\mathrm{H} 11 \mathrm{~N}$ & $0.8103(7)$ & $0.652(3)$ & $0.3174(11)$ & $0.021^{*}$ \\
\hline $\mathrm{C} 11$ & 0.91055 (13) & $0.6951(3)$ & $0.38026(10)$ & $0.0185(4)$ \\
\hline $\mathrm{C} 12$ & 0.90609 (12) & $0.7096(3)$ & $0.25516(9)$ & $0.0156(4)$ \\
\hline $\mathrm{C} 13$ & $0.84323(12)$ & $0.7751(3)$ & $0.20604(9)$ & 0.0179 (4) \\
\hline H13 & 0.7802 & 0.7967 & 0.2165 & $0.021^{*}$ \\
\hline $\mathrm{C} 14$ & $0.87304(13)$ & $0.8082(3)$ & $0.14206(9)$ & $0.0193(4)$ \\
\hline H14 & 0.8303 & 0.8523 & 0.1084 & $0.023^{*}$ \\
\hline $\mathrm{C} 15$ & $0.96520(13)$ & $0.7774(3)$ & $0.12656(9)$ & $0.0192(4)$ \\
\hline H15 & 0.9854 & 0.8019 & 0.0825 & $0.023^{*}$ \\
\hline $\mathrm{C} 16$ & $1.02797(13)$ & 0.7108 & $0.17527(10)$ & $0.0177(4)$ \\
\hline
\end{tabular}




\begin{tabular}{lllll} 
C17 & $0.99808(13)$ & $0.6749(3)$ & $0.23923(9)$ & $0.0176(4)$ \\
H17 & 1.0404 & 0.6265 & 0.2724 & $0.021^{*}$ \\
C18 & $1.12821(13)$ & $0.6769(3)$ & $0.15808(10)$ & $0.0245(5)$ \\
H18A & 1.1566 & 0.5877 & 0.1904 & $0.037^{*}$ \\
H18B & 1.1622 & 0.7975 & 0.1599 & $0.037^{*}$ \\
H18C & 1.1308 & 0.6234 & 0.1129 & $0.037^{*}$ \\
C19 & $1.05091(14)$ & $0.7744(3)$ & $0.44091(10)$ & $0.0256(5)$ \\
H19A & 1.0493 & 0.6584 & 0.4689 & $0.031^{*}$ \\
H19B & 1.0238 & 0.8806 & 0.4663 & $0.031^{*}$ \\
C20 & $1.14753(15)$ & $0.8193(4)$ & $0.42346(12)$ & $0.0349(5)$ \\
H20A & 1.1840 & 0.8490 & 0.4643 & $0.052^{*}$ \\
H20B & 1.1477 & 0.9291 & 0.3933 & $0.052^{*}$ \\
H20C & 1.1750 & 0.7096 & 0.4012 & $0.052^{*}$ \\
\hline
\end{tabular}

Atomic displacement parameters $\left(\AA^{2}\right)$

\begin{tabular}{lllllll}
\hline & $U^{11}$ & $U^{22}$ & $U^{33}$ & $U^{12}$ & $U^{13}$ & $U^{23}$ \\
\hline S1 & $0.0230(3)$ & $0.0401(3)$ & $0.0140(3)$ & $-0.0017(2)$ & $0.00422(18)$ & $-0.0020(2)$ \\
O1 & $0.0190(7)$ & $0.0284(8)$ & $0.0141(7)$ & $0.0011(6)$ & $-0.0009(5)$ & $-0.0020(6)$ \\
N1 & $0.0155(7)$ & $0.0236(9)$ & $0.0139(8)$ & $0.0005(7)$ & $0.0022(6)$ & $-0.0005(7)$ \\
C1 & $0.0200(9)$ & $0.0174(10)$ & $0.0176(10)$ & $-0.0011(8)$ & $0.0017(7)$ & $0.0017(8)$ \\
C2 & $0.0211(9)$ & $0.0129(9)$ & $0.0132(9)$ & $0.0008(7)$ & $0.0039(7)$ & $0.0011(7)$ \\
C3 & $0.0182(9)$ & $0.0233(11)$ & $0.0178(10)$ & $0.0014(8)$ & $0.0019(7)$ & $0.0004(8)$ \\
C4 & $0.0251(10)$ & $0.0262(11)$ & $0.0157(10)$ & $-0.0002(9)$ & $-0.0014(8)$ & $-0.0010(8)$ \\
C5 & $0.0279(10)$ & $0.0234(11)$ & $0.0133(9)$ & $0.0026(8)$ & $0.0052(7)$ & $-0.0009(8)$ \\
C6 & $0.0205(9)$ & $0.0181(10)$ & $0.0184(10)$ & $-0.0003(8)$ & $0.0052(7)$ & $0.0035(8)$ \\
C7 & $0.0199(9)$ & $0.0203(10)$ & $0.0154(10)$ & $-0.0016(8)$ & $0.0014(7)$ & $0.0020(8)$ \\
C8 & $0.0226(10)$ & $0.0331(12)$ & $0.0221(11)$ & $0.0014(9)$ & $0.0077(8)$ & $0.0024(9)$ \\
C9 & $0.0254(10)$ & $0.0337(12)$ & $0.0155(10)$ & $-0.0020(9)$ & $-0.0057(8)$ & $-0.0002(9)$ \\
C10 & $0.0267(11)$ & $0.0404(14)$ & $0.0329(13)$ & $-0.0041(10)$ & $-0.0037(9)$ & $-0.0003(11)$ \\
S11 & $0.0225(3)$ & $0.0423(3)$ & $0.0127(3)$ & $0.0072(2)$ & $0.00474(18)$ & $0.0035(2)$ \\
O11 & $0.0203(7)$ & $0.0236(8)$ & $0.0137(7)$ & $0.0012(6)$ & $-0.0003(5)$ & $-0.0007(6)$ \\
N11 & $0.0147(7)$ & $0.0238(9)$ & $0.0141(8)$ & $0.0025(7)$ & $0.0027(6)$ & $0.0016(7)$ \\
C11 & $0.0200(9)$ & $0.0200(10)$ & $0.0155(9)$ & $0.0075(8)$ & $0.0027(7)$ & $0.0009(8)$ \\
C12 & $0.0196(9)$ & $0.0152(9)$ & $0.0121(9)$ & $-0.0005(7)$ & $0.0031(7)$ & $0.0003(7)$ \\
C13 & $0.0154(9)$ & $0.0225(10)$ & $0.0158(10)$ & $-0.0017(8)$ & $0.0006(7)$ & $-0.0010(8)$ \\
C14 & $0.0219(9)$ & $0.0217(10)$ & $0.0141(9)$ & $-0.0031(8)$ & $-0.0032(7)$ & $0.0010(8)$ \\
C15 & $0.0242(10)$ & $0.0225(10)$ & $0.0110(9)$ & $-0.0033(8)$ & $0.0030(7)$ & $0.0001(8)$ \\
C16 & $0.0198(9)$ & $0.0161(9)$ & $0.0175(10)$ & $-0.0014(8)$ & $0.0042(7)$ & $-0.0007(8)$ \\
C17 & $0.0201(9)$ & $0.0165(9)$ & $0.0162(10)$ & $0.0029(8)$ & $0.0010(7)$ & $0.0010(8)$ \\
C18 & $0.0236(10)$ & $0.0286(12)$ & $0.0217(11)$ & $0.0038(9)$ & $0.0090(8)$ & $0.0029(9)$ \\
C19 & $0.0265(10)$ & $0.0323(12)$ & $0.0176(10)$ & $0.0042(9)$ & $-0.0044(8)$ & $-0.0055(9)$ \\
C20 & $0.0302(12)$ & $0.0359(14)$ & $0.0382(14)$ & $-0.0012(10)$ & $-0.0047(10)$ & $-0.0008(11)$ \\
& & & & & & \\
& & & & & &
\end{tabular}

Geometric parameters $\left(\AA,{ }^{o}\right)$

\begin{tabular}{llll}
\hline $\mathrm{S} 1-\mathrm{C} 1$ & $1.6768(19)$ & $\mathrm{S} 11-\mathrm{C} 11$ & $1.6752(19)$ \\
$\mathrm{O} 1-\mathrm{C} 1$ & $1.321(2)$ & $\mathrm{O} 11-\mathrm{C} 11$ & $1.319(2)$
\end{tabular}




\begin{tabular}{|c|c|c|c|}
\hline $\mathrm{O} 1-\mathrm{C} 9$ & $1.457(2)$ & $\mathrm{O} 11-\mathrm{C} 19$ & $1.454(2)$ \\
\hline $\mathrm{N} 1-\mathrm{C} 1$ & $1.338(2)$ & $\mathrm{N} 11-\mathrm{C} 11$ & $1.339(2)$ \\
\hline $\mathrm{N} 1-\mathrm{C} 2$ & $1.421(2)$ & $\mathrm{N} 11-\mathrm{C} 12$ & $1.423(2)$ \\
\hline $\mathrm{N} 1-\mathrm{H} 1 \mathrm{~N}$ & $0.872(9)$ & $\mathrm{N} 11-\mathrm{H} 11 \mathrm{~N}$ & $0.872(9)$ \\
\hline $\mathrm{C} 2-\mathrm{C} 3$ & $1.394(3)$ & $\mathrm{C} 12-\mathrm{C} 13$ & $1.393(3)$ \\
\hline $\mathrm{C} 2-\mathrm{C} 7$ & $1.397(2)$ & $\mathrm{C} 12-\mathrm{C} 17$ & $1.393(2)$ \\
\hline $\mathrm{C} 3-\mathrm{C} 4$ & $1.378(3)$ & $\mathrm{C} 13-\mathrm{C} 14$ & $1.380(3)$ \\
\hline $\mathrm{C} 3-\mathrm{H} 3$ & 0.9500 & $\mathrm{C} 13-\mathrm{H} 13$ & 0.9500 \\
\hline $\mathrm{C} 4-\mathrm{C} 5$ & $1.388(3)$ & $\mathrm{C} 14-\mathrm{C} 15$ & $1.389(3)$ \\
\hline $\mathrm{C} 4-\mathrm{H} 4$ & 0.9500 & $\mathrm{C} 14-\mathrm{H} 14$ & 0.9500 \\
\hline $\mathrm{C} 5-\mathrm{C} 6$ & $1.391(3)$ & $\mathrm{C} 15-\mathrm{C} 16$ & $1.389(3)$ \\
\hline $\mathrm{C} 5-\mathrm{H} 5$ & 0.9500 & C15-H15 & 0.9500 \\
\hline $\mathrm{C} 6-\mathrm{C} 7$ & $1.390(3)$ & $\mathrm{C} 16-\mathrm{C} 17$ & $1.383(3)$ \\
\hline $\mathrm{C} 6-\mathrm{C} 8$ & $1.510(3)$ & $\mathrm{C} 16-\mathrm{C} 18$ & $1.513(2)$ \\
\hline $\mathrm{C} 7-\mathrm{H} 7$ & 0.9500 & C17-H17 & 0.9500 \\
\hline $\mathrm{C} 8-\mathrm{H} 8 \mathrm{~A}$ & 0.9800 & C18-H18A & 0.9800 \\
\hline $\mathrm{C} 8-\mathrm{H} 8 \mathrm{~B}$ & 0.9800 & $\mathrm{C} 18-\mathrm{H} 18 \mathrm{~B}$ & 0.9800 \\
\hline $\mathrm{C} 8-\mathrm{H} 8 \mathrm{C}$ & 0.9800 & $\mathrm{C} 18-\mathrm{H} 18 \mathrm{C}$ & 0.9800 \\
\hline $\mathrm{C} 9-\mathrm{C} 10$ & $1.480(3)$ & $\mathrm{C} 19-\mathrm{C} 20$ & $1.479(3)$ \\
\hline C9- $\mathrm{H} 9 \mathrm{~A}$ & 0.9900 & C19-H19A & 0.9900 \\
\hline С9-H9B & 0.9900 & C19-H19B & 0.9900 \\
\hline $\mathrm{C} 10-\mathrm{H} 10 \mathrm{~A}$ & 0.9800 & $\mathrm{C} 20-\mathrm{H} 20 \mathrm{~A}$ & 0.9800 \\
\hline $\mathrm{C} 10-\mathrm{H} 10 \mathrm{~B}$ & 0.9800 & $\mathrm{C} 20-\mathrm{H} 20 \mathrm{~B}$ & 0.9800 \\
\hline $\mathrm{C} 10-\mathrm{H} 10 \mathrm{C}$ & 0.9800 & $\mathrm{C} 20-\mathrm{H} 20 \mathrm{C}$ & 0.9800 \\
\hline $\mathrm{C} 1-\mathrm{O} 1-\mathrm{C} 9$ & $118.72(15)$ & $\mathrm{C} 11-\mathrm{O} 11-\mathrm{C} 19$ & $119.01(15)$ \\
\hline $\mathrm{C} 1-\mathrm{N} 1-\mathrm{C} 2$ & $132.48(16)$ & $\mathrm{C} 11-\mathrm{N} 11-\mathrm{C} 12$ & $129.60(16)$ \\
\hline $\mathrm{C} 1-\mathrm{N} 1-\mathrm{H} 1 \mathrm{~N}$ & $115.6(15)$ & $\mathrm{C} 11-\mathrm{N} 11-\mathrm{H} 11 \mathrm{~N}$ & $117.9(15)$ \\
\hline $\mathrm{C} 2-\mathrm{N} 1-\mathrm{H} 1 \mathrm{~N}$ & $111.9(15)$ & $\mathrm{C} 12-\mathrm{N} 11-\mathrm{H} 11 \mathrm{~N}$ & $112.0(15)$ \\
\hline $\mathrm{O} 1-\mathrm{C} 1-\mathrm{N} 1$ & $113.71(16)$ & $\mathrm{O} 11-\mathrm{C} 11-\mathrm{N} 11$ & $113.39(16)$ \\
\hline $\mathrm{O} 1-\mathrm{C} 1-\mathrm{S} 1$ & $124.23(14)$ & $\mathrm{O} 11-\mathrm{C} 11-\mathrm{S} 11$ & $125.00(15)$ \\
\hline $\mathrm{N} 1-\mathrm{C} 1-\mathrm{S} 1$ & $122.06(14)$ & $\mathrm{N} 11-\mathrm{C} 11-\mathrm{S} 11$ & $121.61(15)$ \\
\hline $\mathrm{C} 3-\mathrm{C} 2-\mathrm{C} 7$ & $119.42(17)$ & $\mathrm{C} 13-\mathrm{C} 12-\mathrm{C} 17$ & $119.95(17)$ \\
\hline $\mathrm{C} 3-\mathrm{C} 2-\mathrm{N} 1$ & $115.45(16)$ & $\mathrm{C} 13-\mathrm{C} 12-\mathrm{N} 11$ & $116.33(16)$ \\
\hline $\mathrm{C} 7-\mathrm{C} 2-\mathrm{N} 1$ & $125.13(17)$ & $\mathrm{C} 17-\mathrm{C} 12-\mathrm{N} 11$ & $123.68(17)$ \\
\hline $\mathrm{C} 4-\mathrm{C} 3-\mathrm{C} 2$ & $120.17(17)$ & $\mathrm{C} 14-\mathrm{C} 13-\mathrm{C} 12$ & $119.62(17)$ \\
\hline $\mathrm{C} 4-\mathrm{C} 3-\mathrm{H} 3$ & 119.9 & $\mathrm{C} 14-\mathrm{C} 13-\mathrm{H} 13$ & 120.2 \\
\hline $\mathrm{C} 2-\mathrm{C} 3-\mathrm{H} 3$ & 119.9 & $\mathrm{C} 12-\mathrm{C} 13-\mathrm{H} 13$ & 120.2 \\
\hline $\mathrm{C} 3-\mathrm{C} 4-\mathrm{C} 5$ & $120.51(18)$ & $\mathrm{C} 13-\mathrm{C} 14-\mathrm{C} 15$ & $120.40(17)$ \\
\hline $\mathrm{C} 3-\mathrm{C} 4-\mathrm{H} 4$ & 119.7 & $\mathrm{C} 13-\mathrm{C} 14-\mathrm{H} 14$ & 119.8 \\
\hline $\mathrm{C} 5-\mathrm{C} 4-\mathrm{H} 4$ & 119.7 & $\mathrm{C} 15-\mathrm{C} 14-\mathrm{H} 14$ & 119.8 \\
\hline $\mathrm{C} 4-\mathrm{C} 5-\mathrm{C} 6$ & $119.90(18)$ & $\mathrm{C} 14-\mathrm{C} 15-\mathrm{C} 16$ & $120.16(17)$ \\
\hline $\mathrm{C} 4-\mathrm{C} 5-\mathrm{H} 5$ & 120.0 & $\mathrm{C} 14-\mathrm{C} 15-\mathrm{H} 15$ & 119.9 \\
\hline $\mathrm{C} 6-\mathrm{C} 5-\mathrm{H} 5$ & 120.0 & $\mathrm{C} 16-\mathrm{C} 15-\mathrm{H} 15$ & 119.9 \\
\hline $\mathrm{C} 7-\mathrm{C} 6-\mathrm{C} 5$ & $119.81(17)$ & $\mathrm{C} 17-\mathrm{C} 16-\mathrm{C} 15$ & $119.61(17)$ \\
\hline $\mathrm{C} 7-\mathrm{C} 6-\mathrm{C} 8$ & $119.97(18)$ & $\mathrm{C} 17-\mathrm{C} 16-\mathrm{C} 18$ & $120.42(18)$ \\
\hline $\mathrm{C} 5-\mathrm{C} 6-\mathrm{C} 8$ & $120.21(17)$ & $\mathrm{C} 15-\mathrm{C} 16-\mathrm{C} 18$ & $119.96(17)$ \\
\hline $\mathrm{C} 6-\mathrm{C} 7-\mathrm{C} 2$ & $120.18(18)$ & $\mathrm{C} 16-\mathrm{C} 17-\mathrm{C} 12$ & $120.22(18)$ \\
\hline
\end{tabular}




\begin{tabular}{|c|c|c|c|}
\hline $\mathrm{C} 6-\mathrm{C} 7-\mathrm{H} 7$ & 119.9 & $\mathrm{C} 16-\mathrm{C} 17-\mathrm{H} 17$ & 119.9 \\
\hline $\mathrm{C} 2-\mathrm{C} 7-\mathrm{H} 7$ & 119.9 & $\mathrm{C} 12-\mathrm{C} 17-\mathrm{H} 17$ & 119.9 \\
\hline $\mathrm{C} 6-\mathrm{C} 8-\mathrm{H} 8 \mathrm{~A}$ & 109.5 & $\mathrm{C} 16-\mathrm{C} 18-\mathrm{H} 18 \mathrm{~A}$ & 109.5 \\
\hline $\mathrm{C} 6-\mathrm{C} 8-\mathrm{H} 8 \mathrm{~B}$ & 109.5 & $\mathrm{C} 16-\mathrm{C} 18-\mathrm{H} 18 \mathrm{~B}$ & 109.5 \\
\hline $\mathrm{H} 8 \mathrm{~A}-\mathrm{C} 8-\mathrm{H} 8 \mathrm{~B}$ & 109.5 & $\mathrm{H} 18 \mathrm{~A}-\mathrm{C} 18-\mathrm{H} 18 \mathrm{~B}$ & 109.5 \\
\hline $\mathrm{C} 6-\mathrm{C} 8-\mathrm{H} 8 \mathrm{C}$ & 109.5 & $\mathrm{C} 16-\mathrm{C} 18-\mathrm{H} 18 \mathrm{C}$ & 109.5 \\
\hline $\mathrm{H} 8 \mathrm{~A}-\mathrm{C} 8-\mathrm{H} 8 \mathrm{C}$ & 109.5 & $\mathrm{H} 18 \mathrm{~A}-\mathrm{C} 18-\mathrm{H} 18 \mathrm{C}$ & 109.5 \\
\hline $\mathrm{H} 8 \mathrm{~B}-\mathrm{C} 8-\mathrm{H} 8 \mathrm{C}$ & 109.5 & $\mathrm{H} 18 \mathrm{~B}-\mathrm{C} 18-\mathrm{H} 18 \mathrm{C}$ & 109.5 \\
\hline $\mathrm{O} 1-\mathrm{C} 9-\mathrm{C} 10$ & $106.11(17)$ & $\mathrm{O} 11-\mathrm{C} 19-\mathrm{C} 20$ & $107.04(17)$ \\
\hline $\mathrm{O} 1-\mathrm{C} 9-\mathrm{H} 9 \mathrm{~A}$ & 110.5 & $\mathrm{O} 11-\mathrm{C} 19-\mathrm{H} 19 \mathrm{~A}$ & 110.3 \\
\hline $\mathrm{C} 10-\mathrm{C} 9-\mathrm{H} 9 \mathrm{~A}$ & 110.5 & $\mathrm{C} 20-\mathrm{C} 19-\mathrm{H} 19 \mathrm{~A}$ & 110.3 \\
\hline $\mathrm{O} 1-\mathrm{C} 9-\mathrm{H} 9 \mathrm{~B}$ & 110.5 & $\mathrm{O} 11-\mathrm{C} 19-\mathrm{H} 19 \mathrm{~B}$ & 110.3 \\
\hline $\mathrm{C} 10-\mathrm{C} 9-\mathrm{H} 9 \mathrm{~B}$ & 110.5 & $\mathrm{C} 20-\mathrm{C} 19-\mathrm{H} 19 \mathrm{~B}$ & 110.3 \\
\hline $\mathrm{H} 9 \mathrm{~A}-\mathrm{C} 9-\mathrm{H} 9 \mathrm{~B}$ & 108.7 & $\mathrm{H} 19 \mathrm{~A}-\mathrm{C} 19-\mathrm{H} 19 \mathrm{~B}$ & 108.6 \\
\hline $\mathrm{C} 9-\mathrm{C} 10-\mathrm{H} 10 \mathrm{~A}$ & 109.5 & $\mathrm{C} 19-\mathrm{C} 20-\mathrm{H} 20 \mathrm{~A}$ & 109.5 \\
\hline $\mathrm{C} 9-\mathrm{C} 10-\mathrm{H} 10 \mathrm{~B}$ & 109.5 & $\mathrm{C} 19-\mathrm{C} 20-\mathrm{H} 20 \mathrm{~B}$ & 109.5 \\
\hline $\mathrm{H} 10 \mathrm{~A}-\mathrm{C} 10-\mathrm{H} 10 \mathrm{~B}$ & 109.5 & $\mathrm{H} 20 \mathrm{~A}-\mathrm{C} 20-\mathrm{H} 20 \mathrm{~B}$ & 109.5 \\
\hline $\mathrm{C} 9-\mathrm{C} 10-\mathrm{H} 10 \mathrm{C}$ & 109.5 & $\mathrm{C} 19-\mathrm{C} 20-\mathrm{H} 20 \mathrm{C}$ & 109.5 \\
\hline $\mathrm{H} 10 \mathrm{~A}-\mathrm{C} 10-\mathrm{H} 10 \mathrm{C}$ & 109.5 & $\mathrm{H} 20 \mathrm{~A}-\mathrm{C} 20-\mathrm{H} 20 \mathrm{C}$ & 109.5 \\
\hline $\mathrm{H} 10 \mathrm{~B}-\mathrm{C} 10-\mathrm{H} 10 \mathrm{C}$ & 109.5 & $\mathrm{H} 20 \mathrm{~B}-\mathrm{C} 20-\mathrm{H} 20 \mathrm{C}$ & 109.5 \\
\hline $\mathrm{C} 9-\mathrm{O} 1-\mathrm{C} 1-\mathrm{N} 1$ & $178.80(17)$ & $\mathrm{C} 19-\mathrm{O} 11-\mathrm{C} 11-\mathrm{N} 11$ & $178.92(17)$ \\
\hline $\mathrm{C} 9-\mathrm{O} 1-\mathrm{C} 1-\mathrm{S} 1$ & $-1.1(3)$ & $\mathrm{C} 19-\mathrm{O} 11-\mathrm{C} 11-\mathrm{S} 11$ & $-0.6(3)$ \\
\hline $\mathrm{C} 2-\mathrm{N} 1-\mathrm{C} 1-\mathrm{O} 1$ & $-3.2(3)$ & $\mathrm{C} 12-\mathrm{N} 11-\mathrm{C} 11-\mathrm{O} 11$ & $-3.8(3)$ \\
\hline $\mathrm{C} 2-\mathrm{N} 1-\mathrm{C} 1-\mathrm{S} 1$ & $176.68(16)$ & $\mathrm{C} 12-\mathrm{N} 11-\mathrm{C} 11-\mathrm{S} 11$ & $175.77(16)$ \\
\hline $\mathrm{C} 1-\mathrm{N} 1-\mathrm{C} 2-\mathrm{C} 3$ & $-172.1(2)$ & $\mathrm{C} 11-\mathrm{N} 11-\mathrm{C} 12-\mathrm{C} 13$ & $-147.0(2)$ \\
\hline $\mathrm{C} 1-\mathrm{N} 1-\mathrm{C} 2-\mathrm{C} 7$ & $7.3(3)$ & $\mathrm{C} 11-\mathrm{N} 11-\mathrm{C} 12-\mathrm{C} 17$ & $35.4(3)$ \\
\hline $\mathrm{C} 7-\mathrm{C} 2-\mathrm{C} 3-\mathrm{C} 4$ & $0.2(3)$ & $\mathrm{C} 17-\mathrm{C} 12-\mathrm{C} 13-\mathrm{C} 14$ & $-1.1(3)$ \\
\hline $\mathrm{N} 1-\mathrm{C} 2-\mathrm{C} 3-\mathrm{C} 4$ & $179.66(18)$ & $\mathrm{N} 11-\mathrm{C} 12-\mathrm{C} 13-\mathrm{C} 14$ & $-178.82(17)$ \\
\hline $\mathrm{C} 2-\mathrm{C} 3-\mathrm{C} 4-\mathrm{C} 5$ & $-0.7(3)$ & $\mathrm{C} 12-\mathrm{C} 13-\mathrm{C} 14-\mathrm{C} 15$ & $-0.3(3)$ \\
\hline $\mathrm{C} 3-\mathrm{C} 4-\mathrm{C} 5-\mathrm{C} 6$ & $0.7(3)$ & $\mathrm{C} 13-\mathrm{C} 14-\mathrm{C} 15-\mathrm{C} 16$ & $0.7(3)$ \\
\hline $\mathrm{C} 4-\mathrm{C} 5-\mathrm{C} 6-\mathrm{C} 7$ & $-0.2(3)$ & $\mathrm{C} 14-\mathrm{C} 15-\mathrm{C} 16-\mathrm{C} 17$ & $0.1(3)$ \\
\hline $\mathrm{C} 4-\mathrm{C} 5-\mathrm{C} 6-\mathrm{C} 8$ & $-178.83(19)$ & $\mathrm{C} 14-\mathrm{C} 15-\mathrm{C} 16-\mathrm{C} 18$ & $179.80(18)$ \\
\hline $\mathrm{C} 5-\mathrm{C} 6-\mathrm{C} 7-\mathrm{C} 2$ & $-0.3(3)$ & $\mathrm{C} 15-\mathrm{C} 16-\mathrm{C} 17-\mathrm{C} 12$ & $-1.5(3)$ \\
\hline $\mathrm{C} 8-\mathrm{C} 6-\mathrm{C} 7-\mathrm{C} 2$ & $178.33(18)$ & $\mathrm{C} 18-\mathrm{C} 16-\mathrm{C} 17-\mathrm{C} 12$ & $178.84(18)$ \\
\hline $\mathrm{C} 3-\mathrm{C} 2-\mathrm{C} 7-\mathrm{C} 6$ & $0.3(3)$ & $\mathrm{C} 13-\mathrm{C} 12-\mathrm{C} 17-\mathrm{C} 16$ & $2.0(3)$ \\
\hline $\mathrm{N} 1-\mathrm{C} 2-\mathrm{C} 7-\mathrm{C} 6$ & $-179.08(18)$ & $\mathrm{N} 11-\mathrm{C} 12-\mathrm{C} 17-\mathrm{C} 16$ & $179.53(17)$ \\
\hline $\mathrm{C} 1-\mathrm{O} 1-\mathrm{C} 9-\mathrm{C} 10$ & $-178.76(17)$ & $\mathrm{C} 11-\mathrm{O} 11-\mathrm{C} 19-\mathrm{C} 20$ & $177.42(18)$ \\
\hline
\end{tabular}

Hydrogen-bond geometry $\left(A,{ }^{\circ}\right)$

$\mathrm{Cg} 1$ is the centroid of the (C12-C17) ring.

\begin{tabular}{lllll}
\hline$D-\mathrm{H} \cdots A$ & $D-\mathrm{H}$ & $\mathrm{H} \cdots A$ & $D \cdots A$ & $D-\mathrm{H} \cdots A$ \\
\hline $\mathrm{N} 1-\mathrm{H} 1 N \cdots \mathrm{S} 11$ & $0.87(1)$ & $2.62(1)$ & $3.4859(16)$ & $174(2)$ \\
$\mathrm{N} 11-\mathrm{H} 11 N \cdots \mathrm{S} 1$ & $0.87(1)$ & $2.54(1)$ & $3.3985(15)$ & $171(2)$ \\
$\mathrm{C} 3-\mathrm{H} 3 \cdots \mathrm{S} 11$ & 0.95 & 2.86 & $3.708(2)$ & 150
\end{tabular}


supporting information

$\mathrm{C} 13-\mathrm{H} 13 \cdots \mathrm{S} 1$

$\mathrm{C} 17-\mathrm{H} 17 \cdots \mathrm{Cg} 1^{\mathrm{i}}$

Symmetry code: (i) $-x+2, y-1 / 2,-z+1 / 2$.
0.95

0.95
2.94

2.82
$3.7090(19)$

$3.471(2)$
139

127 